\title{
Overexpression of Mcl-1 exacerbates lymphocyte accumulation and autoimmune kidney disease in Ipr mice
}

\author{
Natasha S Anstee ${ }^{1,2}$, Cassandra J Vandenberg ${ }^{1,2}$, Kirsteen J Campbell ${ }^{1,2,4}$, Peter D Hughes ${ }^{3}$, Lorraine A O'Reilly ${ }^{1,2}$ and \\ Suzanne Cory ${ }^{*, 1,2}$
}

Cell death by apoptosis has a critical role during embryonic development and in maintaining tissue homeostasis. In mammals, there are two converging apoptosis pathways: the 'extrinsic' pathway, which is triggered by engagement of cell surface 'death receptors' such as Fas/APO-1; and the 'intrinsic' pathway, which is triggered by diverse cellular stresses, and is regulated by prosurvival and pro-apoptotic members of the Bcl-2 family of proteins. Pro-survival Mcl-1, which can block activation of the proapoptotic proteins, Bax and Bak, appears critical for the survival and maintenance of multiple haemopoietic cell types. To investigate the impact on haemopoiesis of simultaneously inhibiting both apoptosis pathways, we introduced the vavP-Mcl-1 transgene, which causes overexpression of Mcl-1 protein in all haemopoietic lineages, into Fas ${ }^{\text {pr/lpr }}$ mice, which lack functional Fas and are prone to autoimmunity. The combined mutations had a modest impact on myelopoiesis, primarily an increase in the macrophage/monocyte population in Mcl-1tg/lpr mice compared with $\mathrm{Ipr}$ or $\mathrm{Mcl}-1 \mathrm{tg}$ mice. The impact on lymphopoiesis was striking, with a marked elevation in all major lymphoid subsets, including the non-conventional double-negative (DN) T cells $\left(\mathrm{TCR} \beta^{+} \mathrm{CD}^{-} \mathrm{CD}^{-} \mathrm{B}^{-} 2 \mathrm{O}^{+}\right)$characteristic of $\mathrm{Fas} / \mathrm{pr} / \mathrm{pr}$ mice. Of note, the onset of autoimmunity was markedly accelerated in $\mathrm{Mcl}-1 \mathrm{tg} / \mathrm{lpr}$ mice compared with Ipr mice, and this was preceded by an increase in immunoglobulin (Ig)-producing cells and circulating autoantibodies. This degree of impact was surprising, given the relatively mild phenotype conferred by the vavP-Mcl-1 transgene by itself: a two- to threefold elevation of peripheral $B$ and T cells, no significant increase in the non-conventional DN T-cell population and no autoimmune disease. Comparison of the phenotype with that of other susceptible mice suggests that the development of autoimmune disease in Mcl-1tg/lpr mice may be influenced not only by Ig-producing cells but also other haemopoietic cell types.

Cell Death and Differentiation (2017) 24, 397-408; doi:10.1038/cdd.2016.125; published online 4 November 2016

Cell death by apoptosis has a critical role in maintaining tissue homeostasis and its inhibition can result in autoimmunity and tumour development (for reviews, see Strasser et al. ${ }^{1,2}$ and Moldoveanu et $a l^{3}{ }^{3}$. Apoptosis is executed by certain aspartate-specific cysteine proteases of the caspase family, which are constitutively produced in zymogen form. In mammals, there are two distinct pathways for the activation of such caspases. The 'extrinsic' pathway is triggered by ligation of 'death receptors' of the tumour necrosis factor receptor family, such as Fas, on the plasma membrane. Multimerization of Fas by the trimeric Fas ligand (FasL) results in the formation of a death-inducing signalling complex (DISC), ${ }^{4}$ through recruitment of the FADD adaptor protein and pro-caspase-8 (and, in humans, also pro-caspase-10), which results in auto-activation of this 'initiator' caspase. In contrast, the 'intrinsic' pathway, which is triggered in response to diverse intracellular stresses (e.g., cytokine deprivation, DNA damage) and is regulated by the $\mathrm{Bcl}-2$ protein family, results in permeabilization of the mitochondrial outer membrane (MOM) and release of cytochrome $\mathrm{c}$ into the cytoplasm where it serves as a co-factor for the auto-activation of procaspase- 9 on the apoptosome. For each pathway, activation of the 'initiator' caspase $(-8$ or -9$)$ results in the cleavage and activation of several downstream 'effector' caspases $(-3,-6$ and -7 ), which in turn provoke dismantling of the cell by cleaving scores of vital proteins. The two apoptosis pathways act largely independently although, under certain conditions, Fas signalling results in caspase-8 cleavage of Bid, a proapoptotic member of the Bcl-2 family (see below), which then amplifies the apoptosis signal by bringing the intrinsic pathway into play.

\footnotetext{
${ }^{1}$ Molecular Genetics of Cancer Division, The Walter and Eliza Hall Institute of Medical Research, Melbourne, Victoria, Australia; ${ }^{2}$ Department of Medical Biology, University of Melbourne, Melbourne, Victoria, Australia and ${ }^{3}$ Department of Nephrology, The Royal Melbourne Hospital, Parkville, Victoria, Australia

*Corresponding author: S Cory, Molecular Genetics of Cancer Division, The Walter and Eliza Hall Institute of Medical Research, 1G Royal Parade, Melbourne, VIC 3052 , Australia. Tel: +61 39345 2555; Fax +61 39347 0852; E-mail: cory@wehi.edu.au

${ }^{4}$ Current address: Beatson Institute for Cancer Research, Switchback Road, Glasgow G61 1BD, UK

Abbreviations: ALPS, autoimmune lymphoproliferative syndrome; ANA, anti-nuclear autoantibody; BH3, Bcl-2 homology domain 3; DAPI, 4',6-diamidino-2-phenylindole; DISC, death-inducing signalling complex; DN, double negative; DP, double positive; ELISA, enzyme-linked immunosorbent assay; ELISPOT, enzyme-linked immunoSpot; FCS, foetal calf serum; GN, glomerulonephritis; H\&E, haematoxylin and eosin; Ig, immunoglobulin; MOM, mitochondrial outer membrane; SLE, systemic lupus erythematosus; HRP, horseradish peroxidase; tg, transgenic; WEHI, Walter and Eliza Hall Institute; WT, wild type

Received 09.5.16; revised 12.9.16; accepted 30.9.16; Edited by S Nagata; published online 04.11.2016
} 
The $\mathrm{Bcl}-2$ protein family comprises nearly a score of proand anti-apoptotic proteins, which together operate as a cell life-death switch. ${ }^{1,3,5,6} \mathrm{Bcl}-2$ and its closest homologues (Bcl- $\mathrm{x}_{\mathrm{L}}, \mathrm{Bcl}-\mathrm{w}, \mathrm{Mcl}-1$ and $\left.\mathrm{A} 1 / \mathrm{BFL}-1\right)$ promote MOM integrity, and hence cell survival, by inhibiting activation of very similar but pro-apoptotic homologues, Bax and Bak. Stress, however, upregulates a further group of more distant pro-apoptotic relatives, known as $\mathrm{Bcl}-2$ homology domain 3 (BH3)-only proteins, which bind avidly to the pro-survival Bcl-2-like proteins, thereby neutralizing their capacity to inhibit Bax and Bak. Certain BH3-only proteins (e.g., Bim, Bid and Puma) can facilitate activation of Bax and Bak, by directly inducing their conformational change and homo-dimerization in the MOM. ${ }^{7,8}$ Subsequent homo-oligomerization of the Bax and/or Bak dimers leads to MOM permeabilization and caspase- 9 activation (see above). A recent multi-gene editing study suggests that, in the absence of pro-survival proteins, BH3-only proteins are not required for activation of Bax/Bak, ${ }^{9}$ presumably because these proteins are stochastically unstable in the membrane.

Individual pro-survival Bcl-2-like proteins vary in abundance in different haemopoietic cell types and gene knockout studies have revealed differential dependencies; for example, whereas $\mathrm{Bcl}-2$ primarily sustains the survival of mature lymphoid cells, ${ }^{10}$ $\mathrm{Mcl}-1$ is critical for the survival and maintenance of multiple haemopoietic cell types including haemopoietic stem/progenitor cells, ${ }^{11} \mathrm{~B}$ and T lymphocytes, ${ }^{12-14}$ neutrophils and activated macrophages, ${ }^{15,16}$ and dendritic cells. ${ }^{17}$ Accordingly, reduced $\mathrm{Mcl}-1$ levels severely compromise recovery of haemopoiesis following myeloablative challenge or bone marrow transplantation. ${ }^{18}$

Mcl-1 is the most divergent and short-lived pro-survival protein and has a distinctive interaction profile with its proapoptotic relatives. Like all other pro-survival relatives, it binds the $\mathrm{BH}$-only proteins Bim, $\mathrm{tBid}$ and Puma with high affinity. However, like A1/BFL-1, it also binds strongly to Noxa but fails to bind to Bad, whereas the opposite holds for $\mathrm{Bcl}-2$, $\mathrm{Bcl}-\mathrm{x}_{\mathrm{L}}$ and $\mathrm{Bcl}-\mathrm{w}^{19,20}$ Furthermore, $\mathrm{Mcl}-1$ restrains activation of both Bak and Bax, whereas Bcl-2 only restrains Bax. ${ }^{21-23}$ Unusually, $\mathrm{Mcl}-1$ is found not only on the MOM but also within the mitochondrial matrix, ${ }^{24}$ where it is proposed to regulate mitochondrial bioenergetics.

Genetic studies have established that both the extrinsic and intrinsic apoptosis pathways have a major role in regulating immunity. $^{2,25,26}$ Thus, Fas ${ }^{\text {Ipr/lpr }}$ (hereafter Ipr) mice, ${ }^{27}$ which have a non-functional Fas death receptor, ${ }^{28}$ exhibit severely perturbed lymphopoiesis, developing progressive lymphadenopathy, splenomegaly and autoimmune syndromes (such as glomerulonephritis (GN)) that vary in severity with genetic background; ${ }^{27}$ and humans with Fas mutations develop an autoimmune lymphoproliferative syndrome termed ALPS. ${ }^{29,30}$ Inhibition of the intrinsic pathway via transgenic (tg) overexpression of $\mathrm{Bcl}-2$ results primarily in lymphoid hyperplasia, accompanied by elevated and prolonged antibody responses and, in some situations, autoimmunity. ${ }^{31-34}$ Early studies of $B C L-2 \mathrm{tg} / / \mathrm{pr}^{35}$ and bim $^{-/-} / / \mathrm{pr}$ mice ${ }^{36}$ indicated that simultaneous inhibition of both pathways is synergistic.

In view of the importance of $\mathrm{Mcl}-1$ in regulating haemopoiesis (see above), we have been investigating the impact of its overexpression using a vavP-Mcl-1 transgene, which is expressed in all haemopoietic cell lineages. ${ }^{37}$ We reported previously that vavP-Mcl-1 tg mice develop excess mature $\mathrm{B}$ and $T$ cells but maintain relatively normal numbers of myeloid cells and lack an autoimmune phenotype. ${ }^{37}$ In this study, we have introduced the vavP-Mcl-1 transgene into Ipr mice, to investigate the impact of combined loss of Fas and overexpression of Mcl-1. We found clear evidence of synergy: marked perturbation of lymphopoiesis and a lesser, but significant, impact on myelopoiesis. Of note, autoimmune GN was markedly accelerated in Iprmice expressing the vavP$\mathrm{Mcl}-1$ transgene.

\section{Results}

Overexpression of Mcl-1 markedly exacerbates the Ipr phenotype. VavP-Mcl-1 tg (hereafter $\mathrm{Mcl}-1 \mathrm{tg}$ ) mice were crossed with Fas ${ }^{\text {prl/pr }}$ (hereafter $I p r$ ) mice to generate vavP-Mcl$1 \mathrm{tg} / \mathrm{Fas}^{\mathrm{Ipr} / \mathrm{pr}}$ (hereafter $\mathrm{Mcl}$-1tg//pr) mice. All mice were on a C57BL/6 background, in which the Ipr autoimmune phenotype is less severe than on the autoimmune-prone MRL background. ${ }^{27}$ In vitro tests on $\mathrm{CD}^{+} \mathrm{CD}^{+}$(double positive (DP)) thymocytes showed that, as expected, those from $\mathrm{Mcl}$ $1 \mathrm{tg} / \mathrm{lpr}$ mice were robustly resistant to cell death induced via both the intrinsic and extrinsic apoptosis pathways (Figure 1a). Thus, Mcl-1tg//pr DP thymocytes were refractory to killing induced by the DNA-damaging agent etoposide as well as FasL (Fc-FasL), whereas those from $\mathrm{Mcl}$-1tg mice were resistant to etoposide but sensitive to FasL and those from Ipr mice were profoundly resistant to FasL but sensitive to etoposide.

Endogenous and tg Mcl-1 protein was readily apparent in both lymphoid and myeloid cells of $\mathrm{Mcl}-1 \mathrm{tg}$ and $\mathrm{Mcl}-1 \mathrm{tg} / \mathrm{lpr}$ mice (Figures $1 \mathrm{~b}-\mathrm{h}$ and Campbell et $a l^{37}$ ). The level of endogenous $\mathrm{Mcl}-1$ protein was comparable in all cell types analyzed and tg Mcl-1 (upper band) was present at equivalent or higher levels (Supplementary Figure S1a).

The development of lymphadenopathy and splenomegaly was both accelerated and accentuated in $\mathrm{Mcl}-1 \mathrm{tg} / \mathrm{lpr}$ mice compared with Ipr mice (Figure 2). The differential was apparent as early as 8 weeks of age and became more exaggerated with time (Figure $2 \mathrm{~b}$ and Supplementary Tables S1-3). By 21 weeks, the mean spleen cellularity in $\mathrm{Mcl}-1 \mathrm{tg} / \mathrm{lpr}$ mice was 12-fold higher than in wild type (WT) mice, whereas that in $\mathrm{lpr}$ and $\mathrm{Mcl}-1 \mathrm{tg}$ mice was 2.1- and 1.7-fold higher, respectively.

The blood and haemopoietic tissues were analyzed by immunostaining and flow cytometry (Supplementary Figures S2 and S3) to delineate which cell populations were affected. Myelopoiesis was relatively normal in both $\mathrm{lpr}$ and $\mathrm{Mcl}-1 \mathrm{tg}$ mice, as reported earlier. ${ }^{37-39}$ However, macrophages $\left(\mathrm{Mac}^{+} \mathrm{Gr}^{-}\right)$were significantly elevated in the spleens of $\mathrm{Mcl}-1 \mathrm{tg} / \mathrm{lpr}$ mice compared with either $/ \mathrm{pr}$ or $\mathrm{Mcl}-1 \mathrm{tg}$ mice, being evident as early as 14 weeks and becoming even more prominent with increasing age, whereas granulocytes $\left(\mathrm{Mac}^{+} \mathrm{Gr}^{+}\right)$were only modestly elevated by 21 weeks (Figure 3a left panel). Ter119 ${ }^{+}$erythroid cells were also significantly elevated in the spleen (Supplementary Tables S1-3). In the blood, increased numbers of granulocytes and macrophages were apparent by 21 weeks (Figure 3a right panel) but no major differences were apparent in the bone 
marrow (Supplementary Tables S1-3). Thus, although overexpression of $\mathrm{Mcl}-1$ perturbs myelopoiesis in Ipr mice, the impact, while significant, is relatively modest.
In contrast, there was a profound impact on lymphopoiesis. From an early age, both $\mathrm{T}$ lymphoid (Figure $3 \mathrm{~b}$ ) and $\mathrm{B}$ lymphoid populations (including plasma cells) (Figure $3 \mathrm{c}$,

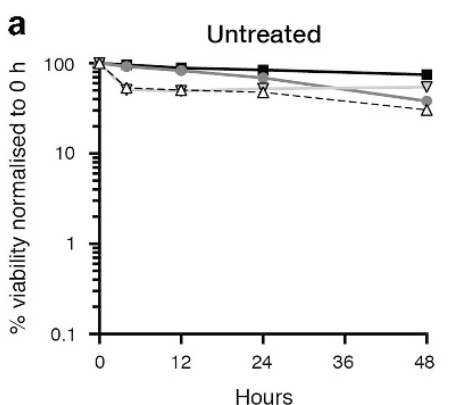

b

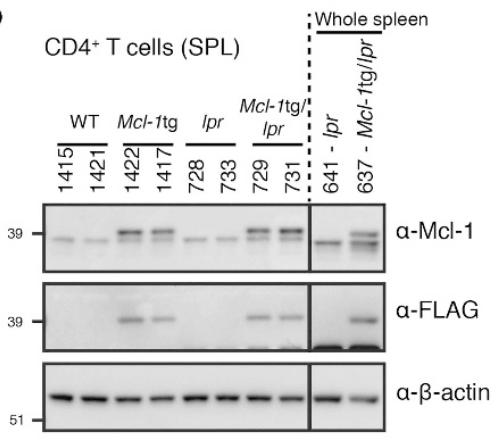

e

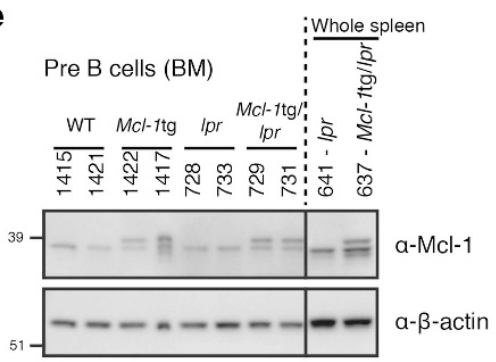

g

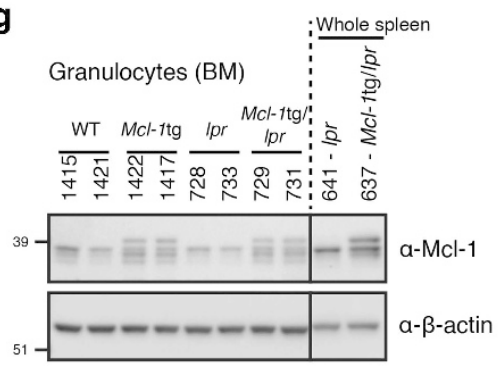

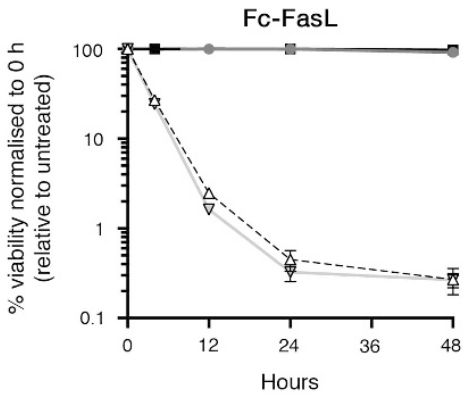

C

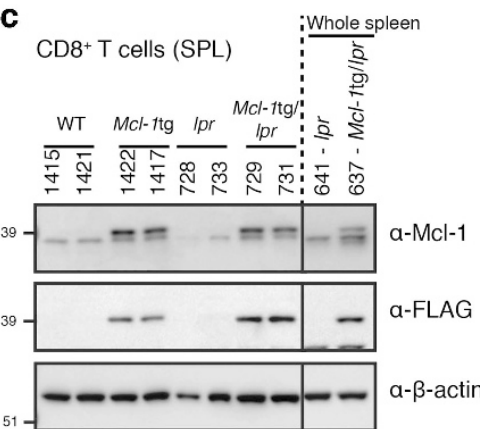

f

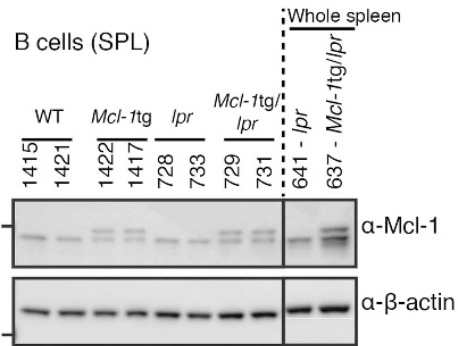

h

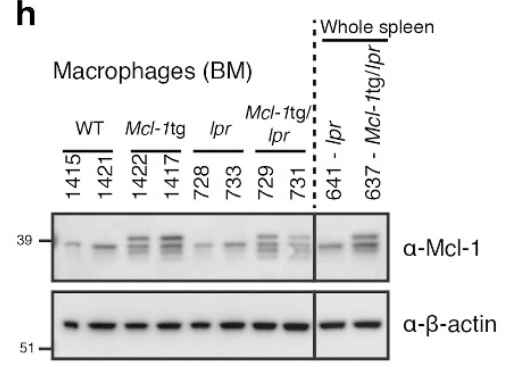

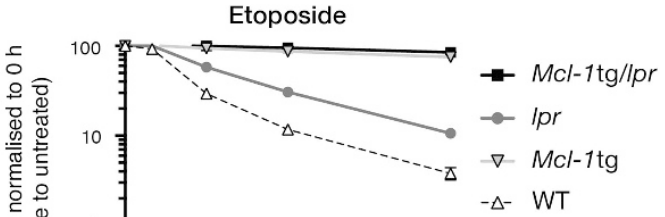

(1)
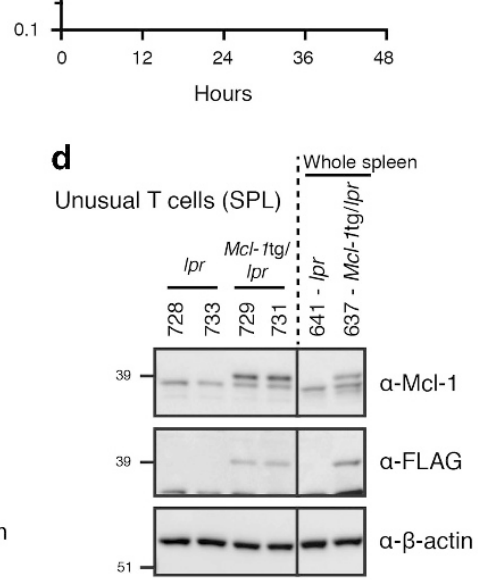

Figure $1 \mathrm{Mcl}-1$ transgene expression in Ipr mice. (a) Lymphocytes from Mcl-1tg//pr mice are resistant to apoptosis triggered through either the intrinsic or extrinsic pathways. Sorted $\mathrm{CD}^{+} \mathrm{CD}^{+}$DP thymocytes from WT, Mcl-1tg, Ipr and Mcl-1tg/lpr mice were cultured in vitro at $50 \times 10^{3} \mathrm{cells}$ in $100 \mu \mathrm{l}$ for $48 \mathrm{~h}$ in medium alone (left panel), medium containing $32 \mathrm{ng} / \mathrm{ml} \mathrm{Fc-FasL} \mathrm{(centre} \mathrm{panel)} \mathrm{or} 1 \mu \mathrm{g} / \mathrm{ml}$ etoposide (right panel). Viability was determined as the proportion of cells negative for PI uptake and annexin $\mathrm{V}$ surface staining, normalized to viability at $0 \mathrm{~h}$. Viability following treatment with Fc-FasL and etoposide are given relative to untreated cells to show stimulus-specific apoptosis. Data represent average response of three independent mice per genotype \pm S.E.M. (b-h) Expression of endogenous and tg Mcl-1 protein in diverse haemopoietic cell types. Western blot analysis of lysates of (b) $\mathrm{CD}^{+} \mathrm{T}$ cells $\left(\mathrm{CD4}^{+} \mathrm{CD} 8^{-}\right),(\mathbf{c}) \mathrm{CD}^{+} \mathrm{T}$ cells $\left(\mathrm{CD} 4^{-} \mathrm{CD} 8^{+}\right)$and (d) unusual T cells $\left(\mathrm{TCR} \beta^{+} \mathrm{CD} 4^{-} \mathrm{CD} 8^{-} \mathrm{B} 22 \mathrm{O}^{+}\right)$sorted from spleen; (e) Pre B cells $\left(\mathrm{CD} 19^{+} \mathrm{lgM}{ }^{-} \mathrm{lgD}\right.$ ) sorted from bone marrow; (f) B cells $\left(\mathrm{CD} 19^{+}\right)$sorted from spleen; (g) granulocytes (Mac1 $\left.{ }^{+} \mathrm{Gr}^{+}\right)$and (h) macrophages $\left(\right.$Mac1 $\left.{ }^{+} \mathrm{Gr} 1^{-}\right)$sorted from bone marrow. Genotypes and mouse identification numbers are indicated. Lysates prepared from whole spleen of /pr mouse \#641 and Mcl-1tg/lpr mouse \#637 were run on each gel to facilitate cross-comparison between different cell types. The solid line indicates electronic removal of two lanes. Each gel was probed with anti-Mcl-1 and anti-FLAG antibodies; because of the presence of the FLAG epitope tag, tg Mcl-1 protein is larger than endogenous Mcl-1. Representative blots of $n=1-4$ experimental replicates. Refer to Supplementary Figure S1 for quantification of blots; sorted myeloid cells and spleen cells appear to contain degraded Mcl-1 making interpretation of relative levels of endogenous and tg Mcl-1 ambiguous 

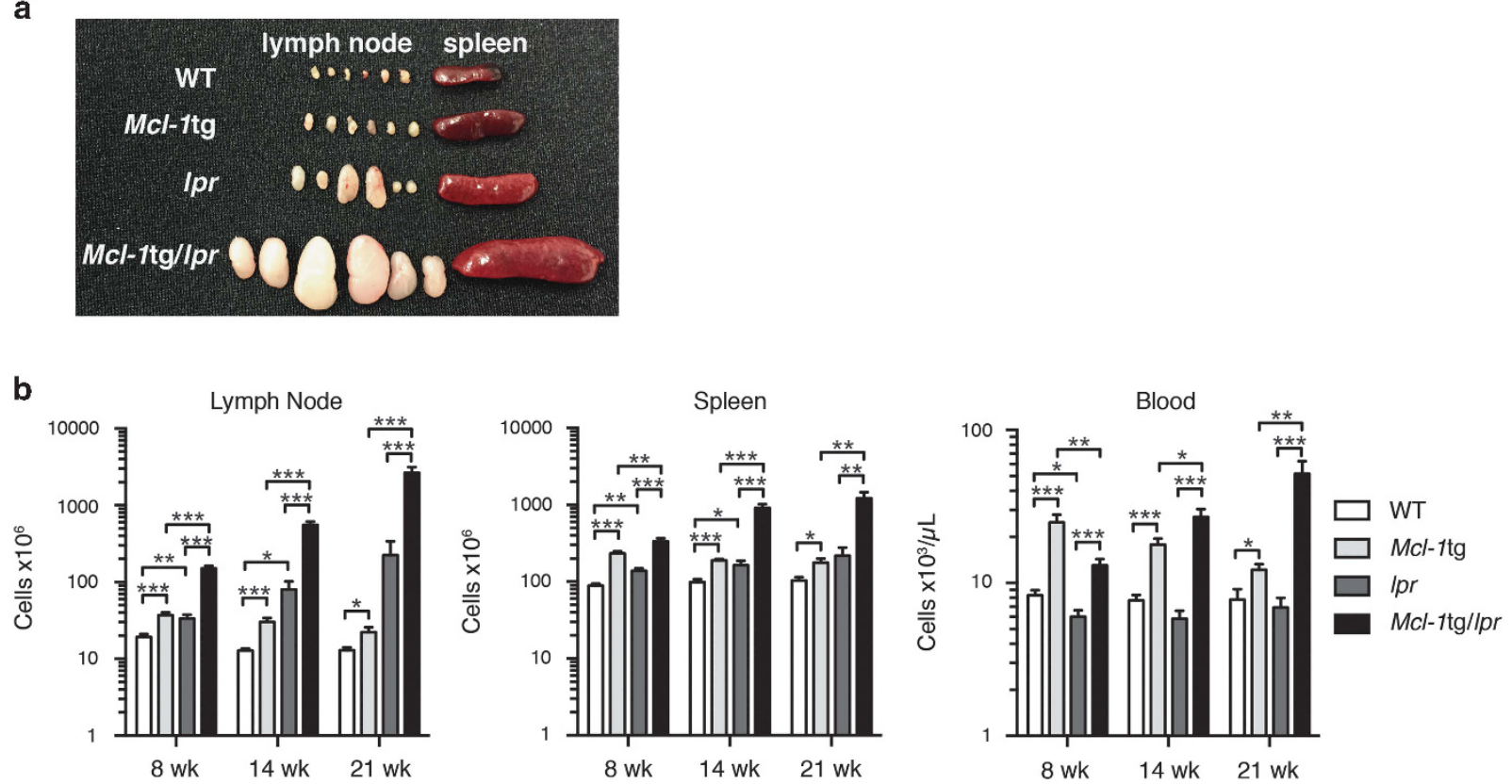

Figure 2 Enhanced splenomegaly and lymphadenopathy in $\mathrm{Mcl}$-1tg//pr mice. (a) Lymph nodes (from left to right, inguinal, axillary and brachial) and spleen dissected from 14-week WT, Mcl-1tg, Ipr, and Mcl-1tg/lpr mice. (b) Total cellularity of lymph nodes (inguinal, axillary and brachial), spleen and peripheral blood of WT (white), Mcl-1tg (light grey), Ipr (dark grey) and $\mathrm{Mcl}$-1tg//pr (black) mice aged 8, 14 and 21 weeks. An equal proportion of male and female mice were used and no difference was observed between genders. Data represent the average of $7-12$ individual mice \pm S.E.M. ${ }^{*} P<0.05$, ${ }^{\star \star} P<0.01,{ }^{\star \star \star}{ }^{*} P<0.001$, calculated by Student's $T$-test with Welch's correction. Refer to Supplementary Tables S1-3 for complete data

Supplementary Figures S3 and S5) were significantly elevated in $\mathrm{Mcl}-1 \mathrm{tg} / \mathrm{lpr}$ mice compared with $\mathrm{lpr}$ or $\mathrm{Mcl}-1 \mathrm{tg}$ mice (see also Supplementary Tables S1-3). The lymphadenopathy in Ipr mice primarily reflects large numbers of nonmalignant non-conventional double-negative (DN) $T$ cells $\left(\mathrm{TCR} \beta^{+} \mathrm{CD} 4^{-} \mathrm{CD} 8^{-} \mathrm{B} 220^{+}\right)$, which are thought to be derived from activated $\mathrm{CD}^{+} \mathrm{T}$ cells that have failed to die because of defective FasL/Fas-mediated apoptosis and have lost CD8 coreceptor expression (see Fortner et al. $^{40}$ ). Mcl-1 overexpression provoked a marked increase in this population: by 21 weeks, an increase of 20- and 25-fold in the spleen and lymph nodes, respectively, was evident in $\mathrm{Mcl}-1 \mathrm{tg} / \mathrm{lp}$ r mice compared with $\mathrm{Ipr}$ mice (Figure $3 \mathrm{~b}$ right panel and Supplementary Table S3). The inference is that both apoptosis pathways control these cells.

Overexpression of $\mathrm{Mcl}-1$ accelerates the morbidity of Ipr mice. Cohorts of mice were aged to investigate whether overexpression of $\mathrm{Mcl}-1$ enhanced the pathological consequences of the Ipr mutation. Mice carrying both mutations became terminally ill prematurely, with a significant reduction in median survival (143 days compared with 341 days, $\mathrm{Mcl}$ $1 \mathrm{tg} / \mathrm{lpr}$ versus $\mathrm{Ipr} P<0.0001$; Figure $4 \mathrm{a})$. Many $\mathrm{Mcl}-1 \mathrm{tg} / \mathrm{lpr}$ mice had to be killed because of excessive weight loss and/or breathing difficulties caused by the severe lymphadenopathy, particularly the massive increase in the size of the cervical and mediastinal lymph nodes. Although several factors may have contributed to the overall morbidity (see further below), the presence of blood in the urine (haematuria) in approximately $75 \%$ of the $\mathrm{Mcl}-1 \mathrm{tg} / \mathrm{lpr}$ and $/ \mathrm{pr}$ mice suggested that kidney damage was also a contributing cause.
Autopsy of sick mice revealed splenomegaly and lymphadenopathy, elevated peripheral white blood cells and reduced platelets, each of these phenotypes being of significantly greater severity in $\mathrm{Mcl}-1 \mathrm{tg} / \mathrm{lpr}$ than $\mathrm{Ipr}$ mice (Figure $4 \mathrm{~b}$ ). In addition, sick mice had one or more of the following symptoms: pale kidneys, mottled liver, mottled lungs and sialitis (inflammation of the submandibular gland), primarily due to lymphocyte infiltration of these organs (Supplementary Figure S4 and data not shown). Although the extent of infiltration and the range of organs affected varied between mice of the same genotype, sick $\mathrm{Mcl}-1 \mathrm{tg} / \mathrm{lpr}$ mice appeared to be more severely affected than Ipr mice.

Kidney sections were scored for GN, characterized by glomerular hypercellularity and leukocyte infiltration (Supplementary Figure S4). Although the proportions of mice with severe GN (pathological score $\geqslant 2$ ) (Figure 4c) or haematuria (Figure 4d) was comparable for sick Ipr and sick $\mathrm{Mcl}-1 \mathrm{tg} / \mathrm{lpr}$ mice, the latter showed a significantly accelerated onset of severe GN (Ipr versus $M c l-1 \mathrm{tg} / / \mathrm{pr} \quad P<0.0001$ ) (Figure 4e).

Polyclonal hypergammaglobulinaemia is a major phenotype of autoimmune disease-prone humans and mice. In Ipr mice, the elevated serum immunoglobulin $(\mathrm{Ig})$ is associated with the deposition of Ig complexes in the renal glomeruli, which is a contributing factor in the development of severe $\mathrm{GN}^{27}$ At 14 weeks of age, before GN onset, significantly elevated levels of IgG1, IgG2a and IgG3 were observed in Ipr mice, whereas serum Ig levels in $\mathrm{Mcl}$-1tg mice were comparable to those in WT mice (Figure 5a). Notably $\mathrm{Mcl}-1 \mathrm{tg} / \mathrm{lpr}$ mice had significantly higher Ig levels than Ipr mice, particularly IgG1 and IgG2a, which are complement-fixing antibodies and can form immune complex deposits, and IgA, which is elevated in 
a

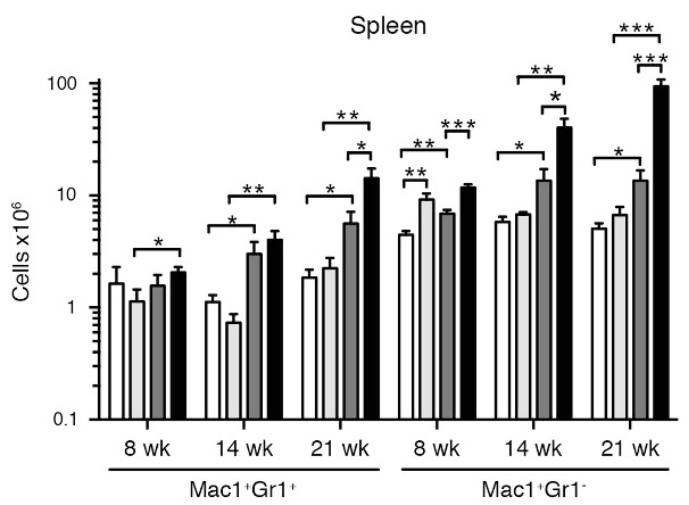

Myeloid

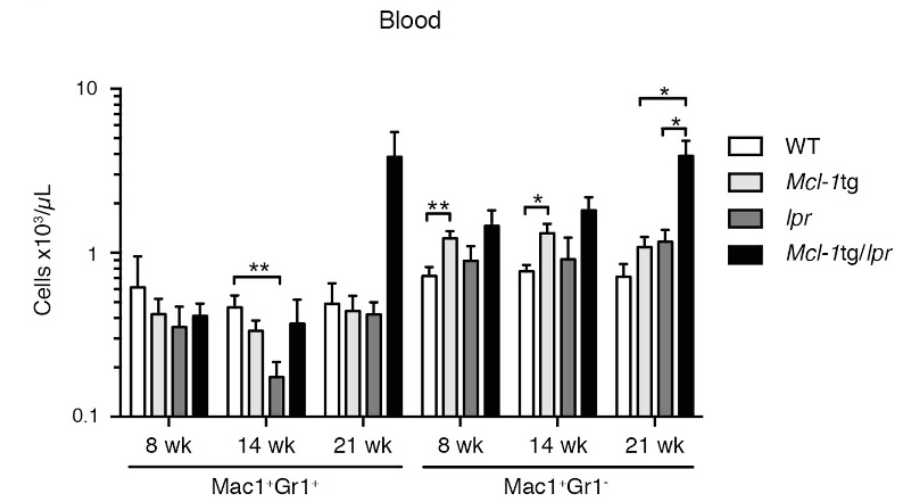

b

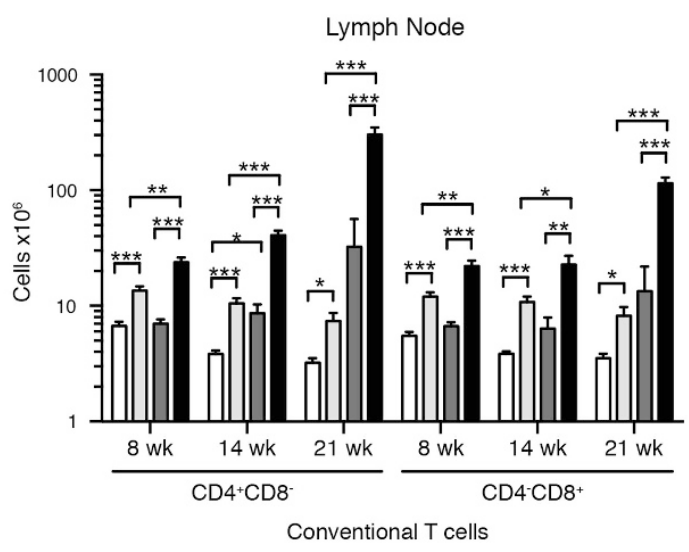

C

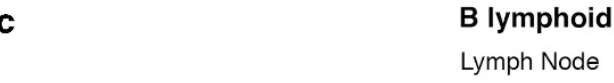

Lymph Node

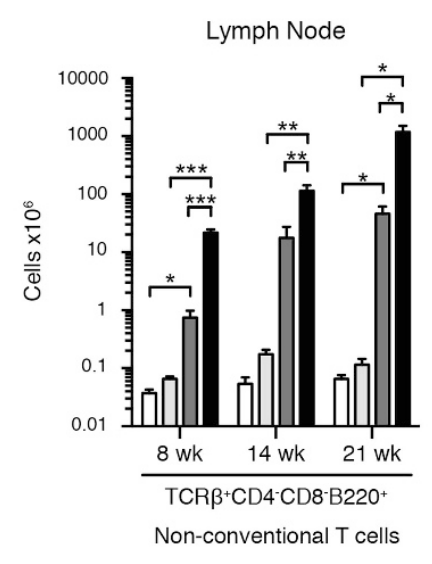

T lymphoid

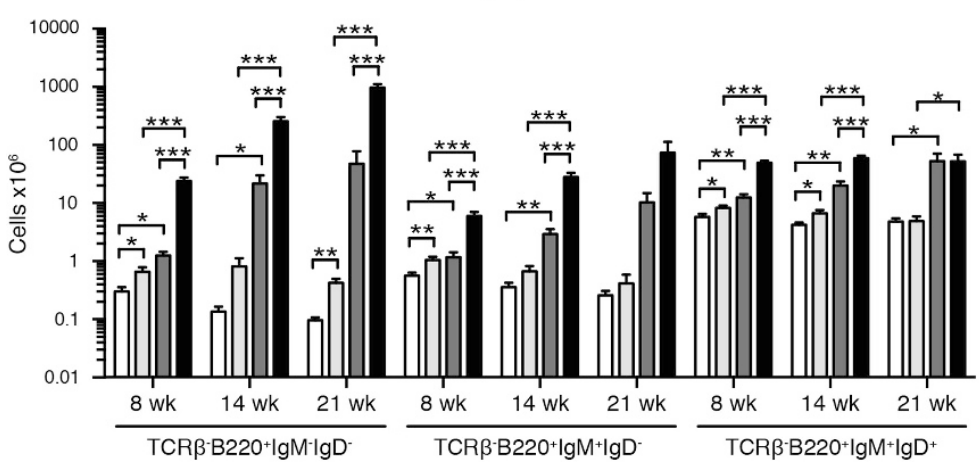

Figure 3 Enhanced splenomegaly and lymphadenopathy in $\mathrm{Mcl}$-1tg//pr mice is primarily due to elevated lymphoid populations. (a) Enumeration of myeloid populations $\left(\mathrm{Mac1}^{+} \mathrm{Gr1}^{+}\right.$and $\mathrm{Mac1}^{+} \mathrm{Gr} 1^{-}$cells) in the spleen and peripheral blood of mice aged 8, 14 and 21 weeks. Data represent the average of 5-12 individual mice \pm S.E.M. (b) Enumeration of conventional T cells ( $\mathrm{CD} 4^{+} \mathrm{CD} 8^{-}$and $\left.\mathrm{CD} 4^{-} \mathrm{CD} 8^{+}\right)$and non-conventional DN T cells $\left(\mathrm{TCR} \beta^{+} \mathrm{CD} 4^{-} \mathrm{CD} 8^{-} \mathrm{B} 22 \mathrm{O}^{+}\right)$; and (c) $\mathrm{B}$ lymphoid populations $\left(\mathrm{B} 22 \mathrm{O}^{+} \mathrm{IgM}{ }^{-} \mathrm{IgD}{ }^{-}\right.$, $\mathrm{B}_{220^{+}} \mathrm{ggM}^{+} \lg \mathrm{D}^{-}$and $\mathrm{B} 220^{+} \mathrm{lgM}{ }^{+} \lg \mathrm{D}^{+}$) in lymph nodes (inguinal, axillary and brachial lymph nodes) of mice aged 8, 14 and 21 weeks. Data represent average of 6-12 individual mice \pm S.E.M. ${ }^{*} P<0.05,{ }^{* *} P<0.01,{ }^{* \star *} P<0.001$, calculated by Student's $T$-test with Welch's correction. An equal proportion of male and female mice were studied, with no gender differences being observed. Refer to Supplementary Tables S1-3 for complete data and Supplementary Figure S2 for gating strategies. Analysis of the B lymphoid compartment using $\mathrm{CD} 19$ as a marker rather than B220 revealed that the $\mathrm{TCR} \beta^{-} \mathrm{B}_{22} 20^{+} \mathrm{IgM}^{-} \mathrm{lg} \mathrm{D}^{-}$population enumerated in (c) contained a number of non-conventional DN T cells with low TCR $\beta$ expression. Thus, although B lymphoid cell numbers were indeed elevated in Mcl-1tg//pr mice compared with /pr mice, the actual increase was less than it had appeared using B220 as the marker: 3-fold at 14 weeks rather than 6-fold (see Supplementary Figure S3 and Supplementary Table S2)

certain forms of renal disease. Consistent with these findings, splenic plasma cells $\left(\mathrm{B} 220^{-} \mathrm{CD} 138^{+}\right)$were elevated in $\mathrm{Mcl}-1 \mathrm{tg} / \mathrm{lpr}$ mice compared with $\mathrm{lpr}$ mice (Supplementary Figure S5, Supplementary Table S2). ELISPOT (enzyme- linked immunoSpot) enumeration (Figure $5 b$ ) also indicated that $\mathrm{Mcl}-1 \mathrm{tg} / \mathrm{Ipr}$ mice had elevated IgM- and IgG-producing cells in the spleen and increased numbers of IgG-producing cells in the bone marrow compared with WT mice. 

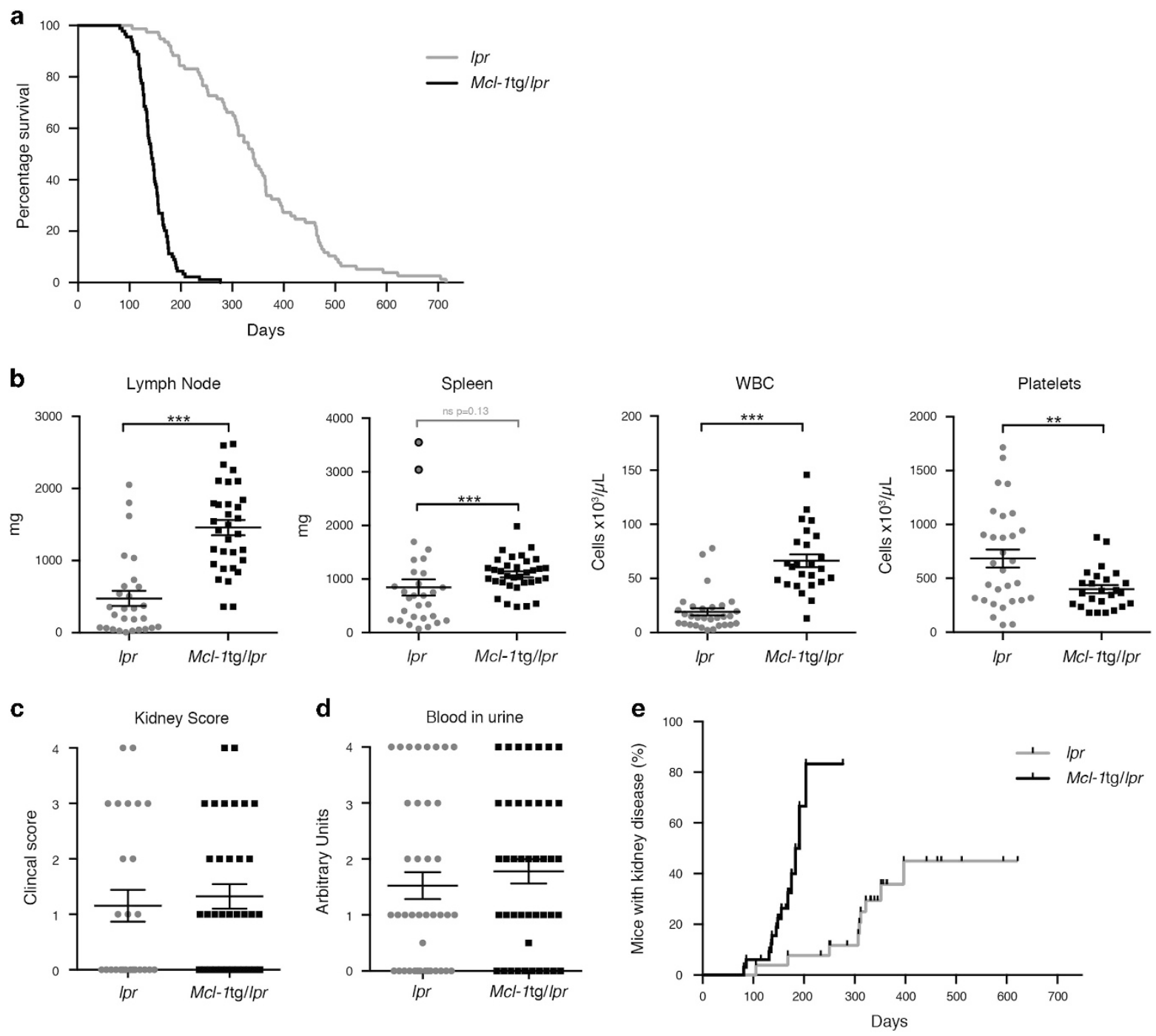

Figure 4 Overexpression of Mcl-1 increases the severity and accelerates the onset of the Ipr autoimmune disease phenotype. (a) Kaplan-Meier plot showing overall survival of $/ p r$ (grey, $n=77$ ) versus Mcl-1tg//pr (black, $n=89$ ) mice. The lifespan of Mcl-1tg//pr mice is significantly reduced compared with $/ p r$ mice $(P<0.0001$, calculated using MantleCox test), median survival being 143 and 341 days, respectively. An equal number of male and female mice were aged for each genotype; no gender difference was observed. (b) Haemopoietic analysis of sick Ipr (grey, $n=28-30$ ) and Mcl-1tg/lpr (black, $n=25-32$ ) mice, including weights of lymph node (inguinal, axillary and brachial) and spleen and enumeration of circulating white blood cells (WBC) and platelets. Data points represent individual mice with mean \pm S.E.M. indicated. ${ }^{* \star} P<0.01,{ }^{* \star *} P<0.001$, calculated by Student's T-test with Welch's correction. Significance for spleen weights is indicated with and without two outlier Ipr mice (black circled points). (c and d) Renal pathology, assessed by (c) GN pathology scoring (score 0-4) and (d) haematuria (scored out of 4) in sick /pr (grey; $n=26-41$ ) and Mcl-1tg//pr (black; $n=34-43$ ) mice. Data points represent individual mice with mean \pm S.E.M. indicated. (e) Kaplan-Meier plot of the incidence of severe GN (clinical score $\geqslant 2$ ) in sick Ipr (grey, $n=26)$ versus sick Mcl-1tg/lpr (black, $n=33$ ) mice, $P<0.0001$ (Mantle-Cox test)

Furthermore, the number of bone marrow-resident IgGproducing cells was significantly higher in $\mathrm{Mcl}-1 \mathrm{tg} / \mathrm{lpr}$ than Ipr mice.

Next, we analyzed the kidneys of sick $/ p r$ and $M c l-1 \mathrm{tg} / / \mathrm{pr}$ mice to ascertain whether the elevated serum $\mathrm{lg}$ was associated with immune complex deposition in the renal glomeruli. IgG-, IgM- and IgA-containing immune complex deposits were detectable in the glomerular capillary loops in a proportion of these mice (Figure $5 c$ and Supplementary Figure S6). However, no difference was apparent between the two genotypes in the severity or proportions of mice having this phenotype (Figure 5d). Although all $/ p r$ and $M c l-1 \mathrm{tg} / / \mathrm{pr}$ mice had immune complex deposits on the mesangial cells, most commonly consisting of IgM, as did some aged WT and $\mathrm{Mcl}-1 \mathrm{tg}$ mice (Figures 5c, d and Supplementary Figure S6), neither mesangial immune complex deposition nor IgM immune complexes is usually associated with glomeruli destruction in human systemic lupus erythematosus (SLE)-associated GN. ${ }^{41}$ These data, together with the clinical score (Figures $4 \mathrm{c}$ and e), suggest that both $/ p r$ and $M c l-1 \mathrm{tg} / / \mathrm{pr}$ mice develop comparable kidney disease, but the $\mathrm{Mcl}-1 \mathrm{tg} / \mathrm{lpr}$ mice experience an accelerated onset (Figure 4e).

Overexpression of Mcl-1 in Ipr mice is associated with increased levels of anti-nuclear autoantibodies. Elevated serum anti-nuclear autoantibodies (ANAs) are one of the 
diagnostic criteria for SLE and certain other autoimmune diseases in humans and mice, including the Ipr strain. To ascertain whether the sick mice had developed autoimmune disease, their sera were analyzed by enzyme-linked immunosorbent assay (ELISA) for the presence of ANAs directed to ssDNA or dsDNA. We found that sick $\mathrm{Mcl}-1 \mathrm{tg} / \mathrm{lpr}$ mice had higher mean IgM ANA levels than sick Ipr mice (Figure 6a). Pertinently, the sera from healthy 21-week-old $\mathrm{Mcl}-1 \mathrm{tg} / \mathrm{lpr}$ mice contained elevated ANAs (both IgM and IgG) compared with age-matched $\mathrm{Mcl}-1 \mathrm{tg}$ and WT mice and elevated IgG ANAs compared with age-matched Ipr mice (Figure 6a). As previously reported, ${ }^{37} \mathrm{Mcl}-1 \mathrm{tg}$ mice did not have significantly elevated ANA levels.

ANAs can also be detected by staining of fixed mitotic HepG2 cells. We found that the ANA levels (immunofluorescent brightness, scored 0-3) were significantly elevated in sera of sick Mcl-1tg/lprcompared with sick Iprmice (Figures $6 \mathrm{~b}$ and c), validating our ELISA assays. Two distinct staining patterns were observed: homogenous staining of the nucleus (denoted nuclear staining) or staining primarily around the nuclear membrane and excluding the nucleus (denoted peripheral staining). A greater proportion of nuclear staining was observed for the $\mathrm{Mcl}-1 \mathrm{tg} / \mathrm{lpr}$ sera compared with the Ipr sera, which produced primarily peripheral or undetectable staining (Figure 6d), however, both patterns are associated with SLE. In conclusion, these data show that overexpression of Mcl-1 increases the levels of autoantibodies in Ipr mice (Figure 6) and, importantly, this can be observed before GN pathology (Figure 6a).

Overexpression of $\mathrm{Mcl}-1$ does not enhance malignant transformation in Ipr mice. As Mcl-1tg mice develop lymphoid tumours with age (median onset, 531 days), ${ }^{37}$ and Ipr mice show a low, albeit significant, incidence of plasmacytomas and T lymphomas at advanced age, ${ }^{42}$ sick $\mathrm{Mcl}-1 \mathrm{tg} / \mathrm{lpr}$ mice were assessed to see if malignant cells were contributing to morbidity. Splenocytes $\left(2 \times 10^{6}\right)$ from sick Ipr (aged 397-463 days) and sick Mcl-1tg/lpr (aged 152-227 days) mice were each transplanted into nonirradiated syngeneic C57BL/6 mice, which were then monitored for survival (Supplementary Table S4). All recipients remained healthy until termination of the experiment (421 days), indicating that frankly malignant cells were not present at measurable frequency in any of the donor spleens.

\section{Discussion}

The intrinsic and extrinsic apoptotic pathways each have critical roles in regulating homeostasis of haemopoietic tissues. $^{2,25,26}$ The study undertaken here has shown that (modest) overexpression of $\mathrm{Mcl}-1$ via the haemopoietic cellspecific vavP-Mcl-1 transgene markedly exacerbates and accelerates the Iprphenotype. The progressive splenomegaly and lymphadenopathy displayed by $I p r$ mice was far more severe in $\mathrm{Mcl}-1 \mathrm{tg} / \mathrm{lpr}$ littermates (Figure 2a). Most of this can be attributed to an expansion of lymphoid (see further below) rather than myeloid cell populations, although the numbers of granulocytes, macrophages and immature erythroid cells were clearly elevated by 21 weeks (particularly in the spleen) (Figure 3, Supplementary Figure S3 and Supplementary
Tables S1-S3). A more severe granulocytic phenotype had been anticipated, given the rapid turnover of granulocytes, ${ }^{43}$ their sensitivity to FasL/Fas-induced apoptosis in vitro, ${ }^{38,44-47}$ genetic evidence that $\mathrm{Mcl}-1$ is critical for granulocyte survival in vivo ${ }^{15}$ and in vitro indications of an interplay between the extrinsic and intrinsic apoptotic pathways in regulating neutrophil survival in vitro. ${ }^{48}$ However, as the transgene is not as highly expressed in granulocytes as in other cell types (Figure $1 \mathrm{~g}$ and Supplementary Figure S1b), the absence of a marked granulocytic phenotype may be due to insufficient overexpression. Alternatively, homeostasis of myeloid cells may primarily involve mechanisms other than the stress and FasL/Fas pathways. Indeed, it seems likely that multiple control processes have evolved to ensure the short lifespan of granulocytes, in order to provide a critical check on the inflammatory response.

In contrast to the modest effect observed on myelopoiesis, overexpression of $\mathrm{Mcl}-1$ greatly increased lymphocyte numbers in Ipr mice, primarily in the spleen and peripheral lymph nodes. Already evident at 8 weeks, the lympho-accumulation became even more prominent with age. All major subsets of lymphoid cells ( $B$ and $T$ ) were elevated, most prominently the non-conventional DN T-cell $\left(\mathrm{TCR} \beta^{+} \mathrm{CD} 4^{-} \mathrm{CD} 8^{-} \mathrm{B} 220^{+}\right)$population, a defining characteristic of $I p r$ mice and human ALPS patients. ${ }^{2}$ Many investigators consider these unconventional $\mathrm{T}$ cells represent previously activated $\mathrm{CD} 8^{+} \mathrm{T}$ cells that have failed to die (see Fortner et al. ${ }^{40}$ ), although this view has been challenged recently with the suggestion that they expand from a rare sub-population in secondary lymphoid organs that are normally removed by FasL/Fas-mediated apoptosis. ${ }^{49}$ Irrespective of their origin, our data suggest that the intrinsic apoptosis pathway limits the expansion of this population.

Morbidity was greatly accelerated in $\mathrm{Mcl}-1 \mathrm{tg} / \mathrm{lpr}$ mice compared with Ipr mice, the median survival being 143 and 341 days, respectively (Figure $4 \mathrm{a}$ ). The $\mathrm{Mcl}-1 \mathrm{tg} / \mathrm{lpr}$ mice had increased lymphadenopathy, splenomegaly, blood cellularity and thrombocytopaenia and their serum Ig and ANA levels were also elevated. Although the clinical severity of the GN, which is caused by deposition of immune complexes within the mesangium and glomerular capillary loops, was comparable in sick /prand $\mathrm{Mcl}-1 \mathrm{tg} / \mathrm{lpr}$ mice (Figures $5 \mathrm{c}$ and d), the onset of GN pathology was significantly accelerated in the latter (Figure $4 \mathrm{e}$ ). This degree of impact was surprising, given the relatively mild phenotype conferred by the vavP-Mcl-1 transgene by itself: a two- to threefold elevation of peripheral $B$ and $T$ cells, no increase in the unusual DN T-cell population and no autoimmune disease (Campbell et al. ${ }^{37}$ and data presented here, Figures 2-6). Overall, our findings suggest that the marked acceleration of morbidity in $\mathrm{Mcl}-1 \mathrm{tg} / \mathrm{lpr}$ mice is due to a combination of the increased severity of the lymphoaccumulation disease (causing respiratory distress) and the accelerated onset of GN (elevated serum Ig levels, autoantibodies and lymphoid infiltration of renal glomeruli). The strong synergy implies that the ( $B$ and $T$ ) lymphoid cells that accumulate when Fas-induced apoptosis fails can still die in response to stress signals, limiting cytokines being a likely source of such stress. More specifically, our data indicate that the Fas and the mitochondrial apoptosis pathways synergize in suppressing autoimmunity.

This report complements previous genetic studies showing that inhibition of the intrinsic apoptosis pathway can 
a
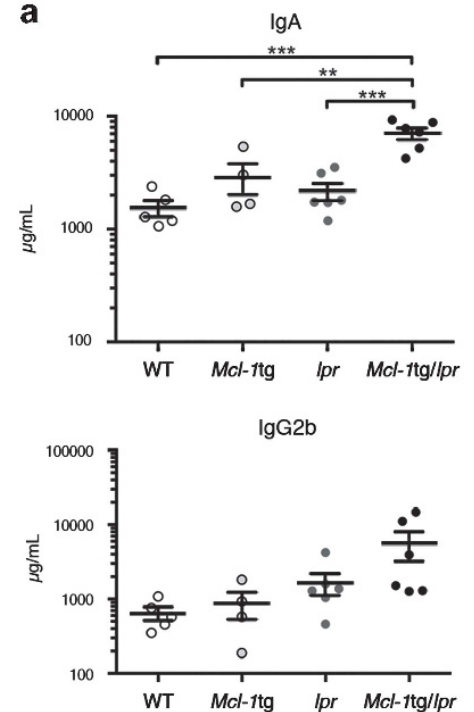

b

C

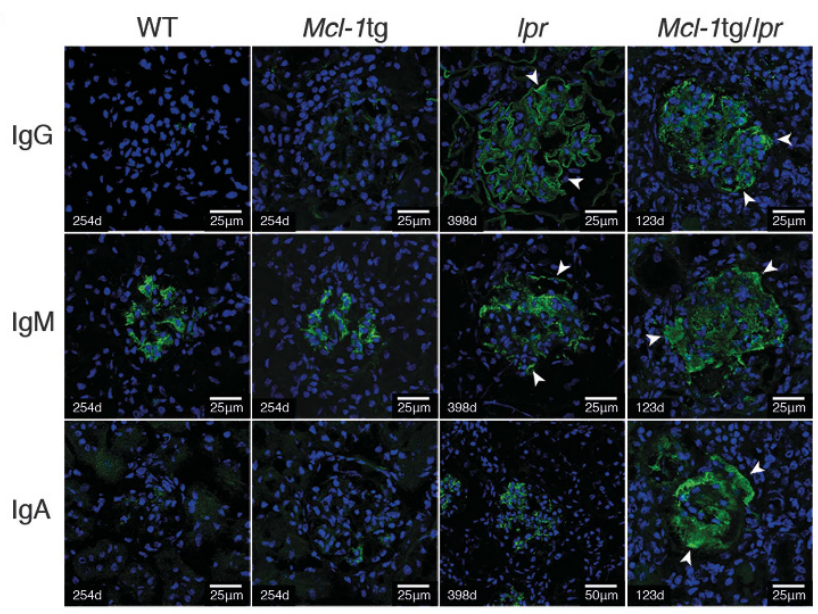

$\lg \mathrm{G} 1$

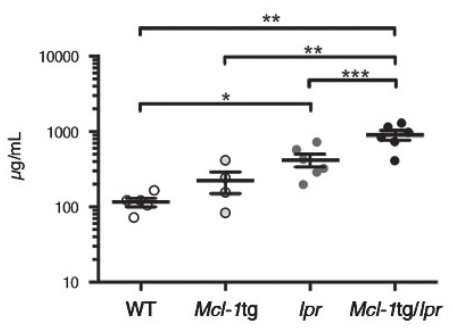

IgG3

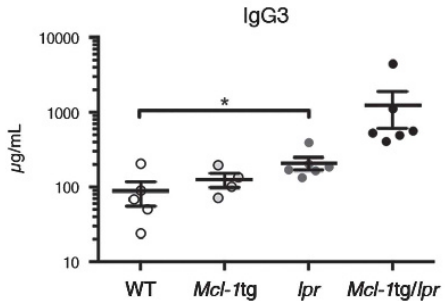

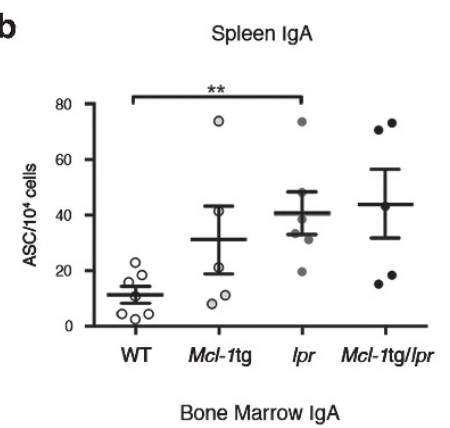

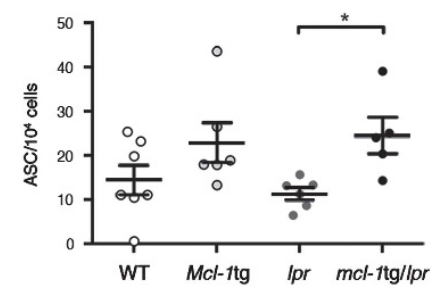

b

○一
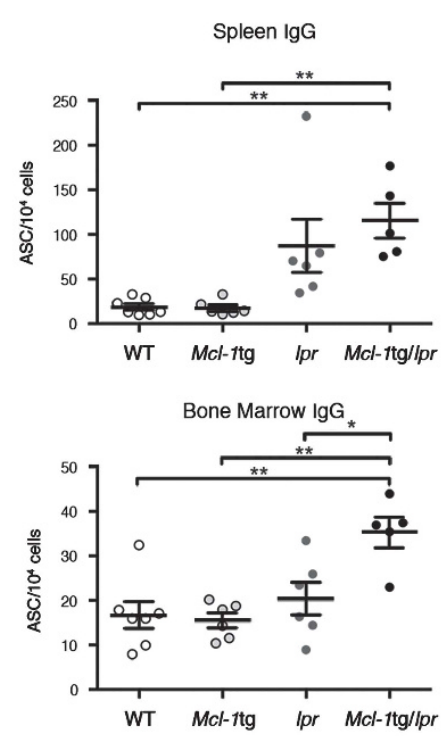
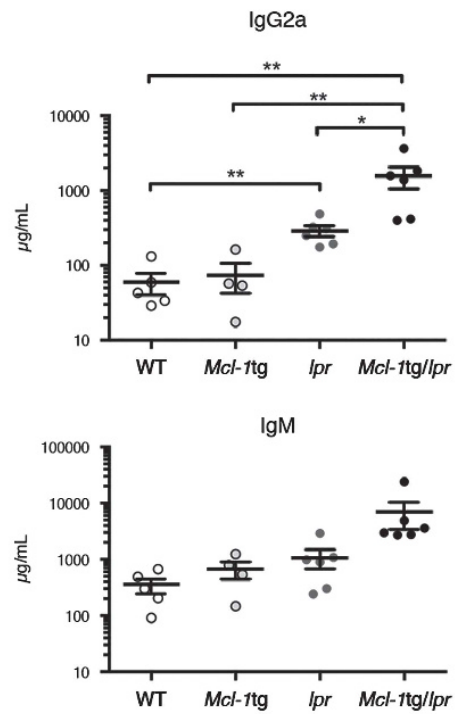
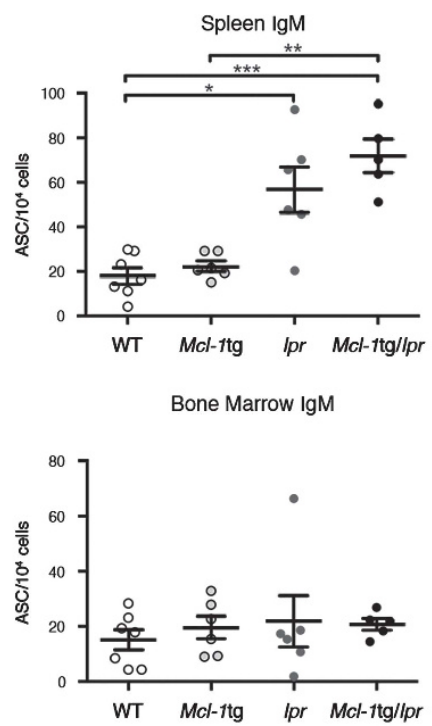

d
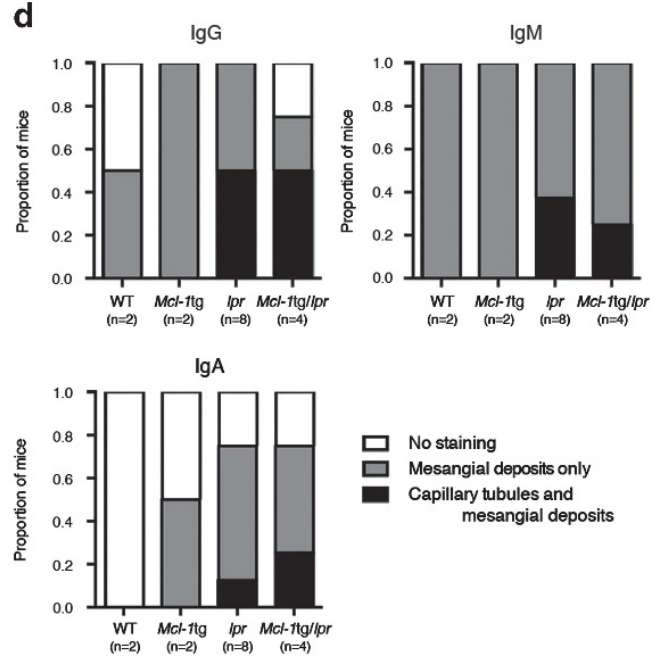

$\square$ No staining

$\square$ Mesangial deposits only

Capillary tubules and mesangial deposits 
Figure 5 Serum Ig levels are elevated in Mcl-1tg//pr mice. (a) ELISA quantification of Ig levels (IgA, lgG1, lgG2a, IgG2b, IgG3 and lgM) in sera of 14-week healthy WT (white, $n=5$ ), Mcl-1tg (light grey, $n=4$ ), Ipr (dark grey, $n=6$ ) and Mcl-1tg/lpr (black, $n=6$ ) mice. Bars represent mean \pm S.E.M. (b) ELISPOT enumeration of the total number of antibody-secreting cells (ASCs) in the spleen and bone marrow (per femur) of healthy 14-week WT (white, $n=7$ ), Mcl-1tg (light grey, $n=6$ ), Ipr (dark grey, $n=6$ ) and Mcl-1tg/lpr (black, $n=5$ ) mice. Data points represent individual mice with mean \pm S.E.M indicated. (c) Representative confocal images of snap frozen kidney sections stained with FITClabelled antibody for the presence of IgG-, IgM- or IgA-deposition (green) in the glomeruli; nuclei are stained with DAPI (blue). One mouse of each genotype is shown. White arrows indicate Ig deposition on the glomerular capillary loops. Scale bar $=25 \mu \mathrm{m}$. (d) Enumeration of staining patterns observed in snap frozen kidney sections analyzed for the presence of IgG-, IgM- or IgA- deposition (see also Supplementary Figure S6). Graphs indicate the proportions of WT $(n=2), M c l-1 \operatorname{tg}(n=2), \operatorname{lpr}(n=8)$ and $M c l-1 \operatorname{tg} / \operatorname{lpr}(n=4)$ kidneys showing no staining of glomeruli (white), staining of Ig deposition on mesangial cells only (grey), or staining of Ig deposition on both glomerular capillary tubules and mesangial cells (black). ${ }^{*} P<0.05,{ }^{* *} P<0.01,{ }^{* * *} P<0.001$, calculated by Student's $T$-test with Welch's correction

exacerbate the Ipr phenotype. ${ }^{35,36,50,51}$ Early crosses of $I p r$ and BCL-2 tg mice (on a mixed C57BL/6 $\times$ SJL background) showed that overexpression of BCL-2 can greatly enhance splenomegaly and lymphadenopathy, primarily due to the accumulation of 'unusual' DN T cells. ${ }^{35,52}$ Combined loss of both Fas and the BH3-only protein Bim (on a C57BL/6 background) also provoked this phenotype, ${ }^{36,40,50}$ accompanied by accumulation of granulocytes and activated macrophages in the spleen and severe GN. ${ }^{50,53}$ Interestingly, the median survival of our $\mathrm{Mcl}-1 \mathrm{tg} / \mathrm{lpr}$ mice is comparable to that of the $\mathrm{Bim}^{+/-} / / \mathrm{pr}$ mice, ${ }^{36}$ indicating that the overexpression of $\mathrm{Mcl}-1$ had less impact than complete loss of Bim. Numerous studies have identified Bim as being vital for inducing apoptosis during development lymphocyte and selection. ${ }^{54-58}$ Presumably the level of $\mathrm{Mcl}-1$ overexpression achieved via the vavP-Mcl-1 transgene was insufficient to neutralize all Bim triggered in vivo.

To put this study into context, it is important to note that inhibition of the intrinsic apoptosis pathway can lead to autoimmune disease even in the absence of mutation of Fas $L$ or Fas. Thus, one of our BCL-2 tg mouse lines, $\mathrm{E} \mu-B C L-2-22$, which was produced on a mixed C57BL/6 x SJL background, was found to develop ANAs and immune complex GN. ${ }^{32}$ This phenotype was dependent on the $B$ lymphoid expression of the $\mathrm{E} \mu-B C L-2-22$ transgene because a contemporaneous line having T-cell restricted expression $(\mathrm{E} \mu-B C L-2-25)$ did not develop autoimmune pathology. ${ }^{59}$ It was also dependent on (unknown) SJL-encoded traits because when $\mathrm{E} \mu$-BCL-2-22 mice were subsequently backcrossed to a C57BL/6 background, the autoimmune phenotype disappeared, ${ }^{59}$ despite the B lymphoid hyperplasia remaining prominent (see Table 1 in Egle et al. ${ }^{34}$ ). More recently, irradiated C57BL/6 mice reconstituted with haemopoietic stem and progenitor cells that are defective in the intrinsic apoptotic pathway, viz foetal liver

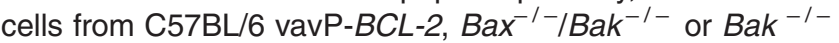
(but not $\mathrm{Bax}^{-1-}$ ) mice, were shown to develop fatal SLE-like GN and multi-organ autoimmune disease associated with polyclonal hypergammaglobulinaemia and ANAs. ${ }^{60}$ Furthermore, C57BL/6 mice with pan-haemopoietic tg expression of BCL-2 (vavP-BCL-2 mice) are highly susceptible to autoimmune kidney disease $\left(25 \%\right.$ by 40 weeks of age).$^{34}$ Pertinently, in addition to elevated B lymphoid populations, C57BL/6 vavP-BCL-2 tg mice ${ }^{33,34}$ have elevated myeloid and T lymphoid populations, as do the $\mathrm{Mcl}-1 \mathrm{tg} / \mathrm{lpr}$ mice described in this study. Therefore, it seems likely that the elevated Ig and autoantibodies resulting from B-cell hyperplasia are necessary but not sufficient for the development of autoimmune kidney disease and that enhanced survival of myeloid and/or T cells is also a requisite factor.

\section{Materials and Methods}

Mice. All mice were bred at the Walter and Eliza Hall Institute (WEHI) and procedures regulated by the WEHI animal ethics committee. To generate vavP-MCl-1tg/Fas ${ }^{\text {pr/pr }}$ (hereafter Mcl-1tg//pr) mice, male vavP-Mcl-1(33) (hereafter Mcl-1tg) mice ${ }^{37}$ were bred with female Fas ${ }^{\text {pr/lpr }}$ (hereafter $/ p r$ ) mice. ${ }^{27}$ Subsequently, $M c l-1 t g / F a s^{\text {prr/pr }}$ males were bred with Fas ${ }^{\text {pr/pr }}$ females to maintain the mouse colony. Age- and sex-matched WT and vavP-Mcl-1(33) mice were used as controls. All mice were on a C57BL/6-WEHI background. To assess pathological impact, cohorts were aged and sick mice were autopsied at ethical endpoint. Healthy mice were also analyzed at 8, 14 and 21 weeks of age. Blood and tissue samples were taken for histology and flow cytometric analysis. Tumorigenicity was tested by injecting spleen cells from sick $\operatorname{Ipr}(n=4)$ or $\mathrm{Mcl}-\mathrm{ftg} / \mathrm{pr}(n=4)$ mice intravenously into syngeneic $\mathrm{C} 57 \mathrm{BL} / 6$ mice $\left(2 \times 10^{6}\right.$ cells per recipient).

Haemopoietic tissue composition. Single-cell suspensions were prepared from spleen, thymus, lymph nodes (axillary, brachial, inguinal) and bone marrow. Red blood cells were removed using $0.168 \mathrm{M}$ ammonium chloride. Peripheral blood cell counts were enumerated using an ADVIA 2120 analyser (Siemens, Erlangen, Germany) and organ cell counts enumerated on a Casy Counter (Scharfe, Reutlingen, Germany). Cell composition was determined by immunostaining and flow cytometry (LSR I flow cytometer, BD Biosciences, Franklin Lakes, NJ, USA), using FlowJo Version 9.3.2 (TreeStar, Ashland, OR, USA). Monoclonal antibodies against cell surface markers were produced and labelled (in-house) with biotin, fluorescein isothiocyanate (FITC), R-phycoerythrin (PE) or allophycocyanin (APC) unless otherwise indicated. Antibodies used included: RA3-6B2, anti-B220; YTA3.2.1, anti-CD4; 53.6.7.2, anti-CD8; 1D3, anti-CD19; RB6-8C5, anti-Gr1; 1145-2C11, anti-lgD; 5.1, anti-lgM; MI/70, antiMac1; T3.24.1, anti-Thy1; H57-59, anti-TCR $\beta$; Ter119, anti-erythroid marker; 187.1, anti-lg $\kappa$ light chain (APC-Cy ${ }^{\mathrm{TM}} 7$ conjugated; BD Biosciences, catalogue \#561353); 281-2, anti-CD138 (PE conjugated; BD Biosciences, catalogue \#558626). Cells stained with biotin-labelled antibodies were secondarily stained with $\mathrm{PE}-\mathrm{CY}^{\mathrm{T}}{ }^{\mathrm{M}} 7$ streptavidin (BD Biosciences, catalogue \#557598) before flow cytometry. Supplementary Figures S2 and S3 show gating strategies.

Histological analysis. Tissue samples were fixed in $10 \%$ formalin, embedded in paraffin wax, sectioned and stained with haematoxylin and eosin (H\&E). Lymphocyte infiltration of tissues was assessed (blinded) using an Olympus BX43 microscope (Olympus, Tokyo, Japan). Photographs were taken with an Olympus DP72 camera (Olympus). H\&E-stained sections of the kidneys were examined by a nephrologist (P Hughes) for evidence of GN and scored (blinded) on a scale of 0-4: $0=$ normal, $1=$ minor mesangial hypercellularity, $2=$ moderate glomerular hypercellularity, $3=$ severe glomerular hypercellularity with thickening of capillary loops, $4=$ severe glomerular hypercellularity with thickening and obliteration of all capillary loops and marked distortion of the glomerular tuft or fibrinoid necrosis or crescent formation. To stain for immune complex deposits, kidneys from WT, Mcl-1tg, Ipr or $\mathrm{Mcl}-1 \mathrm{tg} / \mathrm{pr}$ mice were snap frozen in Tissue-Tek O.C.T. compound (Sakura Finetek Inc., Torrance, CA, USA), sectioned onto Menzel-Glaser Superfrost Plus slides and fixed with acetone. Sections were blocked with phosphate-buffered saline (PBS) supplemented with $2 \%$ foetal calf serum (FCS) and stained with FITC-coupled goat antibodies specific to mouse IgM, IgG or IgA (Southern Biotech, Birmingham, AL, USA) and counterstained with 4',6-diamidino-2-phenylindole (DAPI) to label nuclei. Slides were mounted with Aqua-Poly/Mount (Polyscience Inc., Warrington, PA, USA). Three-dimensional z-stack images were acquired on a Leica SP8 confocal microscope 
a
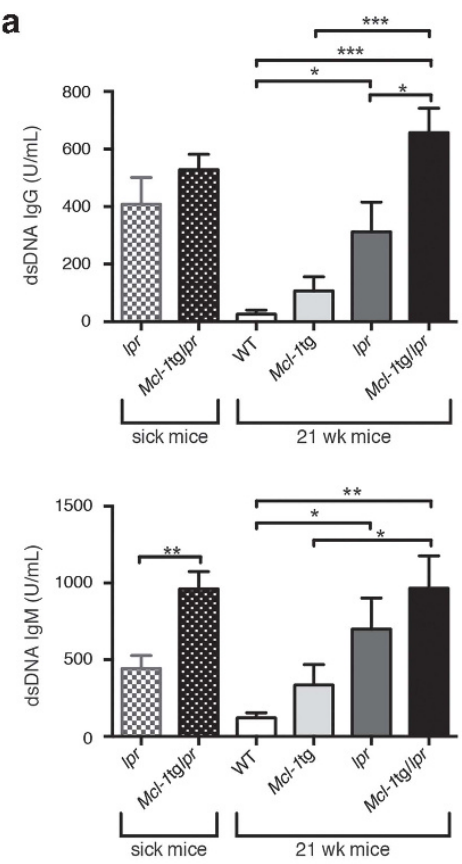
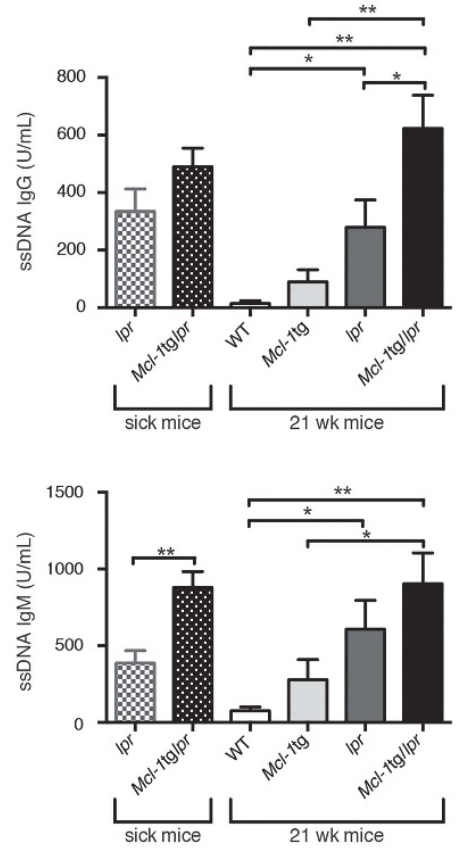

b
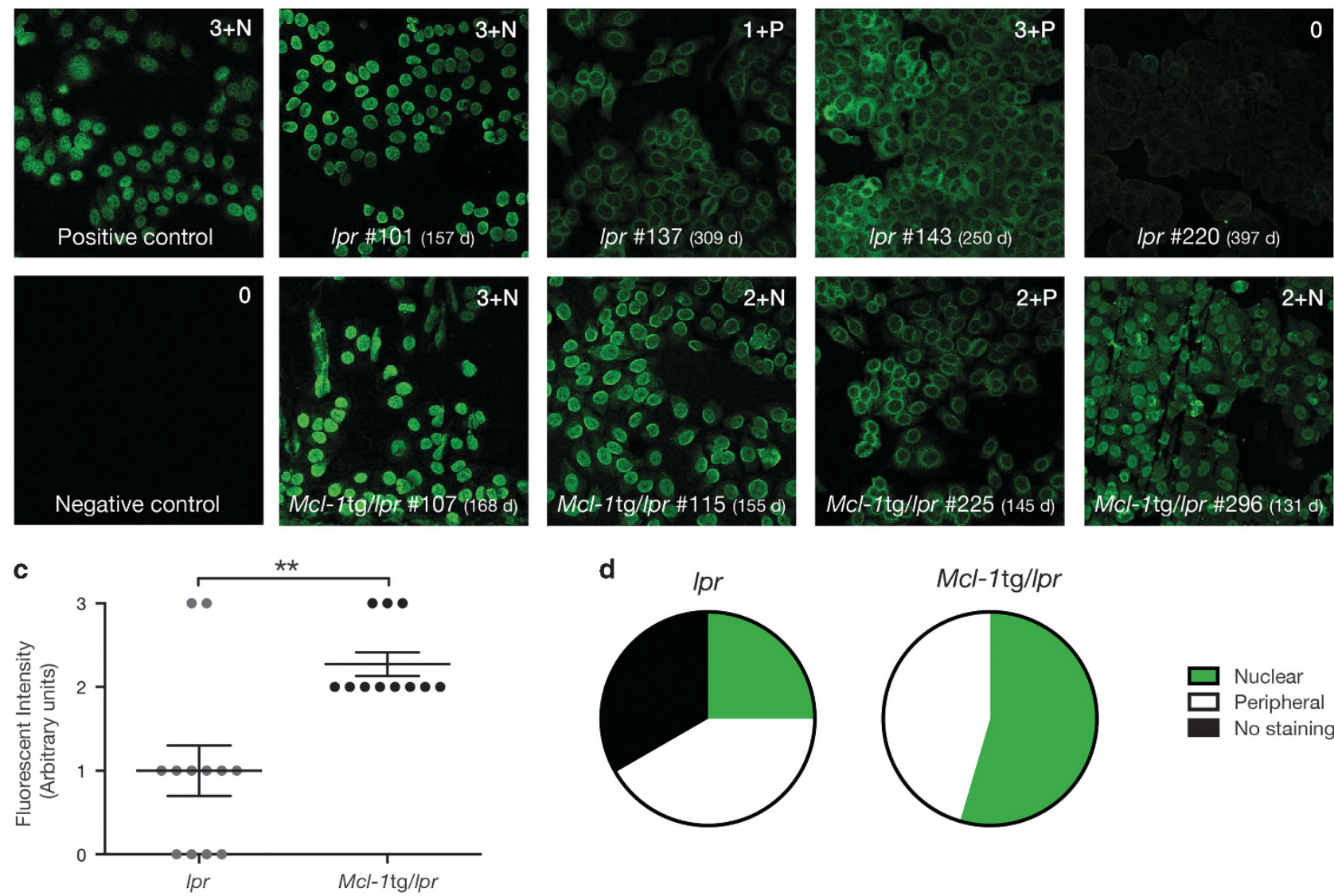

d

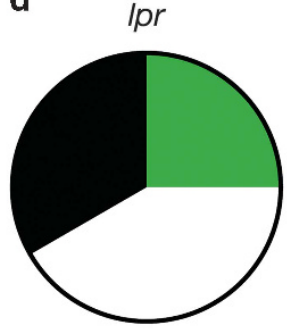

$\mathrm{Mcl}-1 \mathrm{tg} / \mathrm{lpr}$

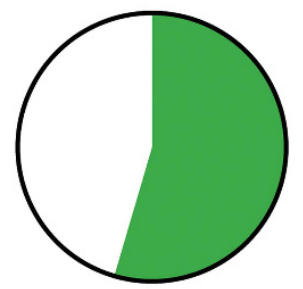

(Leica Microsystems, Wetzlar, Germany) using the galvanometric scanner and a $40 \times 1.3$ N.A. objective with oil. Tile scans of $5 \times 5$ fields of view were also captured using the $8 \mathrm{kHz}$ resonant scanner on the confocal and automatically stitched together with the Leica LAS-X software's algorithm. The final images were then converted to a maximum intensity projection view using the Z-Project feature of FIJI.
In vitro cell viability assay. $\mathrm{CD} 4^{+} \mathrm{CD} 8^{+} \mathrm{DP}$ thymocytes were sorted using a MoFlo (Cytomation, Fort Collins, CO, USA) high-speed sorter and then plated in $100 \mu \mathrm{l}$ of high glucose Dulbecco's modified Eagle's media (DME Kelso) supplemented with $10^{-6} \mathrm{M}$ asparagine (Sigma-Aldrich, St. Louis, MO, USA), $50 \mu \mathrm{M}$ 2-mercaptoethanol (Sigma-Aldrich) and 10\% FCS (Gibco, Mulgrave, VIC, 
Figure 6 ANA levels are elevated in Mcl-1tg//pr mice. (a) ELISA quantification of dsDNA- and ssDNA-specific lgG (top panels) and dsDNA-and ssDNA-specific lgM (bottom panels) (arbitrary units $/ \mathrm{ml}$ ) in sera of sick /pr (checkered dark grey, $n=13$ ) and $M c l-1 \operatorname{tg} / / p r$ (checkered black, $n=13$ ) mice and healthy 21-week WT (white, $n=7$ ), Mcl-1tg (light grey, $n=9$ ), Ipr (dark grey, $n=9$ ) and Mcl-1tg/lpr (black, $n=7$ ) mice. (b) Representative confocal images of Hep-2 cells stained with sera from sick /pr mice or Mcl-1tg/lpr mice. Staining intensity scoring $\left(0\right.$ to $3+$ ) and type of staining ( $N=$ nuclear, $P=$ peripheral) are indicated. Positive control = sera from aged Fas ${ }^{\text {gld } / g l d}$ mouse lacking functional FasL; negative control = sera from 8-week healthy WT mouse. (c) ANA fluorescence intensity of Hep-2 cells, measured in arbitrary units, from sera of sick lpr (grey, $n=12$ ) and Mcl-1tg/lpr (black, $n=11$ ) mice. Data represent mean \pm S.E.M. ${ }^{*} P<0.05,{ }^{* \star} P<0.01,{ }^{* \star *} P<0.001$ calculated by Student's $T$-test with Welch's correction. (d) Patterns of staining: homogenous nuclear staining (green); staining peripheral to the nucleus (white); or no detectable staining (black) for the mice analyzed in (c)

Australia) at a concentration of $50 \times 10^{3}$ cells per well with or without stimulus at a final concentration of $32 \mathrm{ng} / \mathrm{ml} \mathrm{Fc-FasL} \mathrm{(produced} \mathrm{at} \mathrm{WEHI} \mathrm{using} \mathrm{plasmid} \mathrm{ps1117}$ kindly provided by Dr Pascal Schneider, University of Lausanne) or $1 \mu \mathrm{g} / \mathrm{ml}$ etoposide (Pfizer, West Ryde, NSW, Australia). Cell viability was measured using a FACSCalibur (BD Biosciences) 0, 4, 12, 24 and $48 \mathrm{~h}$ after treatment with a cytotoxic stimulus by staining with annexin V-Alexa647 (in-house) and propidium iodide (PI; Sigma-Aldrich). Viability (live cells identified as annexin $\mathrm{V}^{-} \mathrm{PI}^{-}$) was calculated relative to untreated samples to determine the percentage of stimulus-induced apoptosis and then normalized to viability at $0 \mathrm{~h}$.

Immunoblotting. Western blots were performed according to standard procedures using protein lysates prepared from whole spleen samples or sorted cell populations from spleen or bone marrow (sorted using FACSAria, BD Biosciences) using RIPA buffer $(300 \mathrm{mM} \mathrm{NaCl}, 2 \%$ IGEPAL CA-630, $1 \%$ deoxycholic acid, $0.2 \%$ SDS, $100 \mathrm{mM}$ Tris-HCl pH 8.0) containing complete ULTRA protease inhibitors (Roche, Basel, Switzerland) and phenylmethylsulphonyl fluride (Sigma-Aldrich). Samples were run on NuPAGE Bis-Tris $10 \%$ gels (Life Technologies, Carlsbad, CA, USA) with NuPAGE MOPS SDS running buffer (Life Technologies) and transferred to nitrocellulose membranes with an iBlot (Life Technologies). Blots were probed with antibodies to Mcl-1 (clone 19C4-15, WEHI monoclonal facility), Flag (clone 11F3, WEHI monoclonal facility) and $\beta$-actin (clone AC-74, Sigma, catalogue \#A2228), used as a loading control, followed by secondary staining with horseradish peroxidase (HRP)-conjugated rat or mouse lgspecific secondary antibodies (Southern Biotech) and visualized using Luminata Forte western blot HRP substrate (Merck Millipore, Billerica, MA, USA) on a ChemiDoc $^{\text {TM }}$ Touch Imaging System (Bio-Rad, Hercules, CA, USA).

ELISPOT assay. MultiScreen-HA filter plates (Merck Millipore) were coated by incubation overnight at $4{ }^{\circ} \mathrm{C}$ with $2 \mu \mathrm{g} / \mathrm{ml}$ goat anti-mouse $\mathrm{lgM} / \mathrm{G} / \mathrm{A}(\mathrm{H}+\mathrm{L})$ antibodies (Merck Millipore) or $10 \mu \mathrm{g} / \mathrm{ml}$ goat anti-mouse IgA antibodies (Southern Biotech). Plates were washed before adding $1 \times 10^{4}$ or $1 \times 10^{5}$ red cell-depleted spleen or bone marrow cells per well in $200 \mu$ l Iscove's modified Dulbecco's medium supplemented with $10 \%$ FCS and incubated at $37{ }^{\circ} \mathrm{C}$ for $19 \mathrm{~h}$. The plates were washed before incubation with secondary antibodies diluted in block (PBS with $1 \%$ FCS (Gibco), 0.05\% Tween 20 (Sigma) and 0.6\% skim milk powder (Devondale, Brunswick, VIC, Australia)): goat anti-mouse lgG1/lgG2a/lgG2b/lgG3 antibodies conjugated to HRP or goat anti-mouse lgM antibodies conjugated to HRP or goat anti-mouse IgA antibodies conjugated to biotin (all Southern Biotech). For biotinylated antibodies, plates were washed and incubated with streptavidin-HRP (Southern Biotech) diluted in blocking buffer. After further washing, $100 \mu \mathrm{l}$ of substrate solution (250 $\mu \mathrm{g} / \mathrm{ml}$ 3-amino-9-ethylcarbazole (Sigma-Aldrich) in $0.05 \mathrm{M}$ sodium acetate $(\mathrm{pH} 5.0)$ and $0.03 \% \mathrm{H}_{2} \mathrm{O}_{2}$ ) was added to each well. ELISPOTs were counted on an ELISPOT reader (Autoimmun Diagnostika GMBH, Strasburg, Germany).

Serum Igs. Serum Ig levels were determined by ELISA using sheep anti-mouse Ig antibodies (Silenus Laboratories, Hawthorn, VIC, Australia) and mouse Ig isotype-specific goat antibodies conjugated with HRP (Southern Biotech) as previously described. ${ }^{60}$ Absorbance was read at $405 \mathrm{~nm}$ using a VMax microplate reader (Molecular Devices, Sunnyvale, CA, USA). ANAs were quantitated using ELISA kits for detecting mouse anti-dsDNA IgG, anti-ssDNA IgG, anti-dsDNA IgM, anti-ssDNA IgM (Alpha Diagnostics International, San Antonio, TX, USA). Absorbance was read at $450 \mathrm{~nm}$ using a Chameleon plate reader (Hidex, Broomhill, UK). ANAs were also detected by confocal microscopy using the ANA Test system (Immuno Concepts, Sacramento, CA, USA) and slides coated with HEp-2 human epithelial cells, stained according to the manufacturer's instructions, as described. ${ }^{60}$ Images were acquired using an Olympus FV1000 inverted confocal microscope (Olympus) $(60 \times 1.4 \mathrm{~N}$.A with oil). ANA levels were assessed semiquantitatively according to the brightness of fluorescence intensity on a scale of 0 to $3+$.

Statistical analysis. GraphPad Prism (GraphPad Software Inc., San Diego, CA, USA) was used to graph and statistically analyze data. Statistical significance was determined using a two-tailed Student's $T$-test with Welch's correction (assume unequal variance); $P$-values $<0.05$ were considered to be statistically significant. For analysis of Kaplan-Meier mouse survival curves, significance was determined using the log-rank (Mantel-Cox) test.

\section{Conflict of Interest}

The authors declare no conflict of interest.

Acknowledgements. We thank our colleagues A Strasser, P Bouillet and D Gray for useful discussions and advice; C D'Alessandro, S Allan, K Trueman, K Walker and G Siciliano for mouse husbandry; and J Corbin, M Scott and A Lin for excellent technical assistance. This project was supported by NHMRC (Australia) program grants 461221, 1016701 and 1016647, National Cancer Institute grant CA43540, Leukemia and Lymphoma Society Specialized Center for Research grants 7015-02 and 7001-13, PhD fellowship from the Leukemia Foundation of Australia (NSA); postdoctoral fellowships from EMBO and the Human Frontier in Science Program (KJC); and infrastructure support to Walter and Eliza Hall Institute from the National Health and Medical Research (NHMRC) Independent Research Institute Infrastructure Support Scheme and the Victorian State Government Operational Infrastructure Support.

\section{Author contributions}

NSA performed research, analyzed data and wrote the paper. $\mathrm{PH}$ performed histopathology. KJC developed the vavP-Mcl-1 transgenic mouse model. LAO'R and CJV provided expertise, analyzed data and reviewed the paper. SC designed research, analyzed data and wrote the paper.

1. Strasser A, Cory S, Adams JM. Deciphering the rules of programmed cell death to improve therapy of cancer and other diseases. EMBO J 2011; 30: 3667-3683.

2. Strasser A, Jost PJ, Nagata $S$. The many roles of FAS receptor signaling in the immune system. Immunity 2009; 30: 180-192.

3. Moldoveanu T, Follis AV, Kriwacki RW, Green DR. Many players in BCL-2 family affairs. Trends Biochem Sci 2014; 39: 101-111.

4. Lavrik IN, Krammer PH. Regulation of CD95/Fas signaling at the DISC. Cell Death Differ 2012; 19: 36-41.

5. Czabotar PE, Lessene G, Strasser A, Adams JM. Control of apoptosis by the BCL-2 protein family: implications for physiology and therapy. Nat Rev Mol Cell Biol 2014; 15: 49-63.

6. Cory S, Roberts AW, Colman PM, Adams JM. Targeting BCL2-like proteins to kill cancer cells. Trends Cancer 2016; 2: 443-460

7. Czabotar PE, Westphal D, Dewson G, Ma S, Hockings C, Fairlie WD et al. Bax crystal structures reveal how $\mathrm{BH} 3$ domains activate $\mathrm{Bax}$ and nucleate its oligomerization to induce apoptosis. Cell 2013; 152: 519-531.

8. Brouwer JM, Westphal D, Dewson G, Robin AY, Uren RT, Bartolo R et al. Bak core and latch domains separate during activation, and freed core domains form symmetric homodimers. Mol Cell 2014; 55: 938-946.

9. O'Neill KL, Huang K, Zhang J, Chen Y, Luo X. Inactivation of prosurvival Bcl-2 proteins activates Bax/Bak through the outer mitochondrial membrane. Genes Dev 2016; 30 : 973-988.

10. Nakayama K, Nakayama K-I, Negishi I, Kuida K, Sawa H, Loh DY. Targeted disruption of bcl-2ab in mice: occurrence of gray hair, polycystic kidney disease, and lymphocytopenia. Proc Natl Acad Sci USA 1994; 91: 3700-3704

11. Opferman J, Iwasaki $\mathrm{H}$, Ong CC, Suh $\mathrm{H}$, Mizuno S, Akashi $\mathrm{K}$ et al. Obligate role of anti-apoptotic MCL-1 in the survival of hematopoietic stem cells. Science 2005; 307: $1101-1104$ 
12. Opferman JT, Letai A, Beard C, Sorcinelli MD, Ong CC, Korsmeyer SJ. Development and maintenance of $B$ and T lymphocytes requires antiapoptotic MCL-1. Nature 2003; 426: 671-676.

13. Peperzak V, Vikstrom I, Walker J, Glaser SP, LePage M, Coquery CM et al. Mcl-1 is essential for the survival of plasma cells. Nat Immunol 2013; 14: 290-297.

14. Vikstrom I, Carotta S, Luethje K, Peperzak V, Jost PJ, Glaser S et al. Mcl-1 is essential for germinal center formation and B cell memory. Science 2010; 330: 1095-1099.

15. Dzhagalov I St, John A, He YW. The antiapoptotic protein Mcl- 1 is essential for the survival of neutrophils but not macrophages. Blood 2007; 109: 1620-1626.

16. Steimer DA, Boyd K, Takeuchi O, Fisher JK, Zambetti GP, Opferman JT. Selective roles for anti-apoptotic MCL-1 during granulocyte development and macrophage effector function. Blood 2009; 113: 2805-2815.

17. Carrington EM, Zhang JG, Sutherland RM, Vikstrom IB, Brady JL, Soo P et al. Prosurviva $\mathrm{Bcl}-2$ family members reveal a distinct apoptotic identity between conventional and plasmacytoid dendritic cells. Proc Natl Acad Sci USA 2015; 112: 4044-4049.

18. Delbridge AR, Opferman JT, Grabow S, Strasser A. Antagonism between MCL-1 and PUMA governs stem/progenitor cell survival during hematopoietic recovery from stress. Blood 2015; 125: 3273-3280.

19. Chen L, Willis SN, Wei A, Smith BJ, Fletcher JI, Hinds MG et al. Differential targeting of pro-survival Bcl-2 proteins by their BH3-only ligands allows complementary apoptotic function. Mol Cell 2005; 17: 393-403.

20. Kuwana T, Bouchier-Hayes L, Chipuk JE, Bonzon C, Sullivan BA, Green DR et al. BH3 domains of $\mathrm{BH} 3-o n l y$ proteins differentially regulate Bax-mediated mitochondrial membrane permeabilization both directly and indirectly. Mol Cell 2005; 17: 525-535.

21. Willis SN, Chen L, Dewson G, Wei A, Naik E, Fletcher Jl et al. Proapoptotic Bak is sequestered by $\mathrm{Mcl}-1$ and $\mathrm{Bcl}-\mathrm{xL}$, but not $\mathrm{Bcl}-2$, until displaced by BH3-only proteins. Genes Dev 2005; 19: 1294-1305.

22. Willis SN, Fletcher Jl, Kaufmann T, van Delft MF, Chen L, Czabotar PE et al. Apoptosis initiated when BH3 ligands engage multiple Bcl-2 homologs, not Bax or Bak. Science 2007; 315: 856-859.

23. Fletcher Jl, Meusburger S, Hawkins CJ, Riglar DT, Lee EF, Fairlie WD et al. Apoptosis is triggered when prosurvival Bcl-2 proteins cannot restrain Bax. Proc Natl Acad Sci USA 2008; 105: 18081-18087

24. Perciavalle RM, Stewart DP, Koss B, Lynch J, Milasta S, Bathina M et al. Anti-apoptotic MCL-1 localizes to the mitochondrial matrix and couples mitochondrial fusion to respiration. Nat Cell Biol 2012; 14: 575-583.

25. Krammer PH. CD95's deadly mission in the immune system. Nature 2000; 407: 789-795.

26. Strasser A, Bouillet P. The control of apoptosis in lymphocyte selection. Immunol Rev 2003; 193: 82-92.

27. Cohen PL, Eisenberg RA. Lpr and gld: single gene models of systemic autoimmunity and lymphoproliferative disease. Annu Rev Immunol 1991; 9: 243-269.

28. Watanabe-Fukunaga $\mathrm{R}$, Brannan $\mathrm{Cl}$, Copeland NG, Jenkins NA, Nagata S. Lymphoproliferation disorder in mice explained by defects in Fas antigen that mediates apoptosis. Nature 1992; 356: 314-317.

29. Fisher GH, Rosenberg FJ, Straus SE, Dale JK, Middelton LA, Lin AY et al. Dominant interfering Fas gene mutations impair apoptosis in a human autoimmune lymphoproliferative syndrome. Cell 1995; 81: 935-946.

30. Rieux-Laucat F, Le Deist F, Hivroz C, Roberts IAG, Debatin KM, Fischer A et al. Mutations in Fas associated with human lymphoproliferative syndrome and autoimmunity. Science 1995 268: $1347-1349$

31. McDonnell TJ, Nuñez G, Platt FM, Hockenbery D, London L, McKearn JP et al. Deregulated $B c$-2-immunoglobulin transgene expands a resting but responsive immunoglobulin $\mathrm{M}$ and D-expressing B-cell population. Mol Cell Biol 1990; 10: 1901-1907.

32. Strasser A, Whittingham S, Vaux DL, Bath ML, Adams JM, Cory S et al. Enforced BCL2 expression in B-lymphoid cells prolongs antibody responses and elicits autoimmune disease. Proc Natl Acad Sci USA 1991; 88: 8661-8665.

33. Ogilvy S, Metcalf D, Print CG, Bath ML, Harris AW, Adams JM. Constitutive bcl-2 expression throughout the hematopoietic compartment affects multiple lineages and enhances progenitor cell survival. Proc Natl Acad Sci USA 1999; 96: 14943-14948.

34. Egle A, Harris AW, Bath ML, O'Reilly L, Cory S. VavP-Bcl2 transgenic mice develop follicular lymphoma preceded by germinal center hyperplasia. Blood 2004; 103: 2276-2283.

35. Strasser A, Harris AW, Huang DCS, Krammer PH, Bcl-2 Cory S. and Fas/APO-1 regulate distinct pathways to lymphocyte apoptosis. EMBO J 1995; 14: 6136-6147.

36. Hughes PD, Belz GT, Fortner K, Budd RC, Strasser A, Bouillet P. Apoptosis regulators Fas and Bim cooperate in shutdown of chronic immune responses and prevention of autoimmunity. Immunity 2008; 28: 197-205.

37. Campbell KJ, Bath ML, Turner ML, Vandenberg CJ, Bouillet P, Metcalf D et al. Elevated Mcl-1 perturbs lymphopoiesis, promotes transformation of hematopoietic stem/progenitor cells, and enhances drug resistance. Blood 2010; 116: 3197-3207.

38. Fecho K, Bentley SA, Cohen PL. Mice deficient in fas ligand $(g / d)$ or fas (Ipr) show few alterations in granulopoiesis. Cell Immunol 1998; 188: 19-32.

39. Schneider E, Moreau G, Arnould A, Vasseur F, Khodabaccus N, Dy M et al. Increased fetal and extramedullary hematopoiesis in Fas-deficient C57BL/6-Ipr/lpr mice. Blood 1999; 94: 2613-2621.
40. Fortner KA, Bouillet $P$, Strasser A, Budd RC. Apoptosis regulators Fas and Bim synergistically control T-lymphocyte homeostatic proliferation. Eur J Immunol 2010; 40: 3043-3053.

41. Weening JJ, D'Agati VD, Schwartz MM, Seshan SV, Alpers CE, Appel GB et al. The classification of glomerulonephritis in systemic lupus erythematosus revisited. JAm Soc Nephrol 2004; 15: 241-250.

42. Davidson WF, Giese T, Fredrickson TN. Spontaneous development of plasmacytoid tumors in mice with defective Fas-Fas ligand interactions. J Exp Med 1998; 187: 1825-1838.

43. Price TH, Lee MY, Dale DC, Finch CA. Neutrophil kinetics in chronic neutropenia. Blood 1979; 54: 581-594.

44. Lagasse $\mathrm{E}$, Weissman IL. bcl-2 inhibits apoptosis of neutrophils but not their engulfment by macrophages. J Exp Med 1994; 179: 1047-1052.

45. Iwai K, Miyawaki T, Takizawa T, Konno A, Ohta K, Yachie A et al. Differential expression of bcl-2 and susceptibility to anti-Fas-mediated cell death in peripheral blood lymphocytes, monocytes, and neutrophils. Blood 1994; 84: 1201-1208.

46. Liles WC, Kiener PA, Ledbetter JA, Aruffo A, Klebanoff SJ. Differential expression of Fas (CD95) and Fas ligand on normal human phagocytes: implications for the regulation of apoptosis in neutrophils. J Exp Med 1996; 184: 429-440.

47. Villunger A, O'Reilly LA, Holler N, Adams JM, Strasser A. Fas ligand, Bcl-2, G-CSF and p38 MAPK: regulators of distinct cell death and survival pathways in granulocytes. J Exp Med 2000; 192: 647-657.

48. Croker BA, O'Donnell JA, Nowell CJ, Metcalf D, Dewson G, Campbell KJ et al. Fas-mediated neutrophil apoptosis is accelerated by Bid, Bak, and Bax and inhibited by Bcl-2 and Mcl-1. Proc Natl Acad Sci USA 2011; 108: 13135-13140.

49. Martina MN, Noel S, Saxena A, Rabb H, Hamad AR. Double negative (DN) alphabeta T cells: misperception and overdue recognition. Immunol Cell Biol 2015; 93: 305-310.

50. Hutcheson J, Scatizzi JC, Siddiqui AM, Haines GK 3rd, Wu T, Li QZ et al. Combined deficiency of proapoptotic regulators Bim and Fas results in the early onset of systemic autoimmunity. Immunity 2008; 28: 206-217.

51. Weant AE, Michalek RD, Khan IU, Holbrook BC, Willingham MC, Grayson JM. Apoptosis regulators Bim and Fas function concurrently to control autoimmunity and CD8+ T cell contraction. Immunity 2008; 28: 218-230.

52. Reap EA, Felix NJ, Wolthusen PA, Kotzin BL, Cohen PL, Eisenberg RA. Bcl-2 transgenic Lpr mice show profound enhancement of lymphadenopathy. J Immunol 1995; 155 : $5455-5462$.

53. Hughes $\mathrm{P}$, Bouillet $\mathrm{P}$, Strasser $\mathrm{A}$. Role of Bim and other Bcl-2 family members in autoimmune and degenerative diseases. Curr Dir Autoimmun 2006; 9: 74-94.

54. Hildeman DA, Zhu Y, Mitchell TC, Bouillet P, Strasser A, Kappler J et al. Activated T cell death in vivo mediated by pro-apoptotic Bcl-2 family member, Bim. Immunity 2002; 16: 759-767.

55. Bouillet P, Purton JF, Godfrey DI, Zhang L-C, Coultas L, Puthalakath H et al. BH3-only Bcl-2 family member Bim is required for apoptosis of autoreactive thymocytes. Nature 2002; 415 : 922-926.

56. Enders A, Bouillet $\mathrm{P}$, Puthalakath $\mathrm{H}, \mathrm{Xu} \mathrm{Y}$, Tarlinton DM, Strasser A. Loss of the pro-apoptotic $\mathrm{BH} 3$-only $\mathrm{Bcl}-2$ family member Bim inhibits $\mathrm{BCR}$ stimulation-induced apoptosis and deletion of autoreative B cells. J Exp Med 2003; 198: 1119-1126.

57. Fischer SF, Bouillet $P, O^{\prime}$ Donnell K, Light A, Tarlinton DM, Strasser A. Pro-apoptotic $\mathrm{BH}$-only protein Bim is essential for developmentally programmed death of germinal center-derived memory B cells and antibody forming cells. Blood 2007; 110: 3978-3984.

58. Pellegrini M, Belz G, Bouillet $P$, Strasser A. Shut down of an acute T cell immune response to viral infection is mediated by the pro-apoptotic Bcl-2 homology 3-only protein Bim. Proc Natl Acad Sci USA 2003; 100: 14175-14180.

59. Strasser A, Harris AW, Cory S. The role of bcl-2 in lymphoid differentiation and neoplastic transformation. Curr Top Microbiol Immunol 1992; 182: 299-302.

60. Mason KD, Lin A, Robb L, Josefsson EC, Henley KJ, Gray DH et al. Proapoptotic Bak and Bax guard against fatal systemic and organ-specific autoimmune disease. Proc Natl Acad Sci USA 2013; 110: 2599-2604.

This work is licensed under a Creative Commons Attribution-NonCommercial-NoDerivs 4.0 International
License. The images or other third party material in this article are included in the article's Creative Commons license, unless indicated otherwise in the credit line; if the material is not included under the Creative Commons license, users will need to obtain permission from the license holder to reproduce the material. To view a copy of this license, visit http://creativecommons.org/licenses/by-nc-nd/4.0/

(C) The Author(s) 2017 